\title{
The Variation of Microbial Communities in a Depth Profile of an Acidic, Nutrient-Poor Boreal Bog in Southwestern Finland
}

\author{
Irina Tsitko1, Merja Lusa'2, Jukka Lehto², Lauri Parviainen³, Ari T. K. Ikonen ${ }^{3,4}$, \\ Anne-Maj Lahdenperä ${ }^{5}$, Malin Bomberg ${ }^{*}$ \\ ${ }^{1}$ VTT Technical Research Centre of Finland, Espoo, Finland \\ ${ }^{2}$ Laboratory of Radiochemistry, Department of Chemistry, University of Helsinki, Helsinki, Finland \\ ${ }^{3}$ Posiva Oy, Olkiluoto, Finland \\ ${ }^{4}$ Environmental Research and Assessment EnviroCase, Ltd., Pori, Finland \\ ${ }^{5}$ Saanio \& RiekkolaOy, Helsinki, Finland \\ Email: ${ }^{*}$ malin.bomberg@vtt.fi
}

Received 26 August 2014; revised 26 September; accepted 4 October 2014

Copyright (C) 2014 by authors and Scientific Research Publishing Inc.

This work is licensed under the Creative Commons Attribution International License (CC BY).

http://creativecommons.org/licenses/by/4.0/

(c) (i) 0 Den Access

\section{Abstract}

Natural bacterial communities impact the motility of isotopes, such as radionuclides, in the environment. As a result of post glacial crustal rebound radionuclides may escape the deep geological repository for spent nuclear fuel on Olkiluoto Island, Finland, and reach surface environments. Lastensuo Bog, a 5300-year-old raised bog in southwestern Finland, functions as analogue ecotope for bogs formed in Olkiluoto due to the crustal rebound. A core comprising the depth profile $(0-7$ m depth) of the bog including surface Sphagnum moss, peat and bottom clay was obtained using a stainless steel corer. High throughput sequencing was used to characterize the bacterial communities throughout the bog's depth profile. A total of 12,680 bacterial Operational Taxonomic Units (OTUs) (97\% sequence similarity) were detected comprising altogether 40 different bacterial phyla. of these, 13 phyla were present at all depths, accounting for $97 \%-99 \%$ of the whole bacterial community. The bacterial communities differed notably through the bog's depth profile, dividing it into five distinct strata: 1) the Sphagnum moss layer; 2) $0.5-3.7 \mathrm{~m}$; 3) 3.7 - $4.0 \mathrm{~m}$; 4$) 5.5$ - $6.0 \mathrm{~m}$ deep peat; 5) the former seabed clay at $6.5-7.0 \mathrm{~m}$ depth. Acidobacteria, $\alpha$ - and $\gamma$-Proteobacteria dominated the surface community, but in the peat Acidobacteria contributed with up to $85 \%$ of the bacterial community. The estimated bacterial population density ranged between $2 \times 10^{9}$ and $5 \times 1^{10} 16 S$ rRNA gene copies $g^{-1}$ dry-weight peat. This study revealed that Lastensuo Bog had a highly diverse bacterial community. Most of the taxonomic groups belonged to thus far poorly characterized and uncultured bacteria with unknown physiological role. However, new insights into the distribution of bacterial taxa and their putative roles in organic carbon break down with-

*Corresponding author.

How to cite this paper: Tsitko, I., Lusa, M., Lehto, J., Parviainen, L., Ikonen, A.T.K., Lahdenperä, A.-M. and Bomberg, M. (2014) The Variation of Microbial Communities in a Depth Profile of an Acidic, Nutrient-Poor Boreal Bog in Southwestern Finland. Open Journal of Ecology, 4, 832-859. http://dx.doi.org/10.4236/oje.2014.413071 
in the bog ecosystem have been obtained and an important baseline for further studies has been established.

Keywords

Ombotrophic Bog, Peat, Sequencing, Bacterial Community

\section{Introduction}

Pristine wetlands play a significant role in global carbon cycling and function as sinks for atmospheric $\mathrm{CO}_{2}[1]$ [2]. They harbour one third of the global soil carbon pool [3] [4] and are an important global source of methane [5], which is produced during anaerobic degradation of organic matter. Wetlands are important biotopes in northern areas and cover up to one third of the land surface in Finland [6]. In addition, water-logged peatlands might be considerable reservoirs of freshwater in the Northern Hemisphere. Ombotrophic raised bogs represent unique habitats for microorganisms, being very acidic and receiving water and minerals only from precipitation. These conditions favour the dominance of Sphagnum mosses, which form acidic, nutrient-poor, decompositionresistant Sphagnum peat [7] [8].

The Olkiluoto Island, on the west coast of Finland, is selected for deep geological disposal of spent nuclear fuel in Finland. The nuclear waste will be placed in copper-lined cast iron canisters at about $400 \mathrm{~m}$ depth in the bedrock, embedded in bentonite clay in order to protect the canisters and prevent leakage of radionuclides into the environment [9]. After the last deglaciation, Olkiluoto Island lay below the surface of the Baltic Sea, and rose above the sea about 2500 - 3000 years ago [10]. The on-going crustal rebound in the region has changed and changes the coastal area, and within 6000 years the Olkiluoto Island will develop into an inland site and new bogs will form in the area [11]. This is the earliest time considered for radioactive releases from the deep spent fuel repository to be able to reach the biosphere if the nuclear waste canisters were to lose their integrity [12]. In the safety assessment for the long-lived radionuclides present in spent nuclear fuel, the Lastensuo Bog is identified as representative of biotopes expected to develop in Olkiluoto in the future due to crustal rebound [13].

Although wetland microbiology has been studied for decades, progress has been hampered by methodological challenges, such as inability to cultivate the majority of the microorganisms under laboratory conditions [14] [15]. Developments in molecular biology technologies (RLFP, cloning of 16S rRNA gene fragments) in recent years have resulted in an increase in our knowledge of acidic peat microbial inhabitants [14]. Most studies have concentrated on particular groups of microorganisms, such as Proteobacteria, Acidobacteria, Actinobacteria, mehanotrophic or methanogenic microorganisms [16]-[21]. Only a few studies employing high throughput sequencing have been conducted to date to elucidate the whole bacterial community structure in acidic peatlands [15] [22]-[24]. Thus, the structure of the microbial communities and functional roles of many microbial inhabitants of northern wetlands remain unknown.

Sufficient understanding of the function of the microbial community in peat bogs in the region is important to support long-term safety assessments for geological disposal of nuclear waste. The aims of this study included the establishment of a baseline describing the bacterial communities at different depths of Lastensuo Bog, a 5300-year-old raised bog in Finland. This information will be used for further studies focusing on the involvement of the bacteria in the mobilization or impediment of radionuclides. In addition, we aimed to describe the bacterial communities throughout the bog profile in detail and to estimate the main metabolic pathways presented in the bacterial community of Lastensuo Bog.

\section{Materials and Methods}

\subsection{Site Description}

The sampling area, Lastensuo Bog, is located on the western coast of Finland approximately $30 \mathrm{~km}$ north-east of the Olkiluoto repository site. This south-west sloping raised bog is 440 ha in extent and is surrounded by hummocky till soils [11] [25]. The bog is 44 to $48 \mathrm{~m}$ above sea level and the maximum thickness of the peat layer is approximately $6 \mathrm{~m}$. The underlying soil consists of clay and sand originating from the former seabed. Gyttja is found on top of the clay layer. 
In terms of ecotopes, the central bog area consists of treeless or near-treeless Sphagnum fuscum bog, Sphagnum fuscum pine bog, ridge hollow pine bog and hollow bog [11] [25]. Towards the edges the ecotope change from low sedge bog and cotton grass pine bog to tall sedge pine fen and forested peatlands. Of the main peat types, $58 \%$ is Sphagnum peat, $8 \%$ sedge-moss peat, $19 \%$ sedge peat and $15 \%$ few-flowered sedge [25]. According to radiocarbon dating, the peat accumulation in the mire started 5300 years ago, when the area emerged from the Baltic Sea, and the average peat increment has been $1.08 \mathrm{~mm} /$ year [25].

The ecotope at the sampling plot, located at the centre of the bog, is almost treeless hummock-hollow pine bog [11]. The vegetation on the hummocks and hollows of the sampling plot were characterized in 2010 [11] and the vegetation on the hummocks included Eriophorum vaginatum, Erica spp., Rubus chamaemorus, Vaccinium oxycoccus, Sphagnum fuscum, Andromeda polifolia, Vaccinium uliginosum, Empetrum nigrum, Cladina stellaris, Cladonia spp., Cetraria islandica and Dicranum spp. In partly vegetated, partly muddy hollows identified plants included Rhunchospora alba, Scheuzeria palustris and Sphagnum spp.

\subsection{Sampling}

The peat samples from the Lastensuo Bog were collected in May 2011 and June 2013 from one sampling plot $\left(61^{\circ} 17^{\prime} 31^{\prime \prime} \mathrm{N}, 21^{\circ} 50^{\prime} 22^{\prime \prime} \mathrm{E}\right.$, WGS84 coordinate system). The samples collected in 2011 were used for the geochemical characterization of the peat and the peat samples used for the isolation of nucleic acid were collected in 2013. The samples were taken from seven different peat layers: $0.5-1.0 \mathrm{~m}, 1.5-2.0 \mathrm{~m}, 2.5-3.0 \mathrm{~m}, 3.5-3.7 \mathrm{~m}$, $3.7-4.0 \mathrm{~m}, 4.5-5.0 \mathrm{~m}, 5.5-6.0 \mathrm{~m}$ and $6.5-7.0 \mathrm{~m}$. In addition, surface moss, mainly Sphagnum spp. (hereafter referred to as $0 \mathrm{~m}$ ) was collected. The samples were taken using a Russian peat corer, made of stainless steel with a diameter of $15 \mathrm{~cm}$ and a nest length of $50 \mathrm{~cm}$. The samples were placed into $2 \mathrm{~L}$ plastic bags and the sub-samples for nucleic acid isolation were transferred aseptically to sterile $50 \mathrm{ml}$ Falcon tubes. All samples were cooled during transportation and samples for DNA extraction were stored frozen at $-18^{\circ} \mathrm{C}$ until thawed for DNA extraction.

\subsection{Sample Characterization}

From the peat samples dry weight $\left(105^{\circ} \mathrm{C}\right)$ and the organic matter $(\mathrm{OM})$ contents $\left(550^{\circ} \mathrm{C}\right.$, measured by the loss on ignition method) were analyzed as described elsewhere [26]. Humification degree (von Post scale) was estimated based on [27]. The $\mathrm{pH}$ was measured in $0.01 \mathrm{M} \mathrm{CaCl}_{2}$ solution (ISO10390 standard) using a gel-filled electrode. All analyses were performed in triplicate.

\subsection{Nucleic Acid Isolation}

Approximately $0.5 \mathrm{~g}$ subsamples of moss, peat or clay were used for DNA extraction from $0 \mathrm{~m}$ (Sphagnum moss), peat from $0.5-1.0 \mathrm{~m}, 1.5-2.0 \mathrm{~m}, 2.5-3 \mathrm{~m}, 3.5-3.7 \mathrm{~m}, 3.7-4.0 \mathrm{~m}, 5.5-6.0 \mathrm{~m}$ depth and former seabed clay from $6.5-7.0 \mathrm{~m}$ depth. Community DNA was isolated directly from the thawed samples with the Nucleo Spin Soil DNA extraction kit (Macherey-Nagel). Two parallel extractions were performed for each depth one of which was extracted with buffer SL1 (sample a) and the other with buffer SL2 (sample b) with the addition of the enhancer solution, according to the manufacturer's protocol. An additional extraction was performed using the same buffers without the enhancer solution in order to maximize the amount of DNA extracted. The DNA extraction proceeded as instructed by the manufacturer. The DNA was eluted in $100 \mu$ l elution buffer and the DNA concentration of each extract was measured using the NanoDrop-1000 spectrophotometer.

\subsection{Amplicon Library Preparation}

Libraries for 454 high throughput (HTP) amplicon sequencing were prepared by PCR from each DNA extraction. Bacterial 16S rRNA gene fragments covering the V1 - V3 variable regions were amplified with primers $8 \mathrm{~F}$ and P2 [28] [29] equipped with adapter and MID sequences (tags) at their 5' end in a single round PCR as described in [30]. PCRs were performed with the KAPA HiFi polymerase (KapaBiosystems, Inc., Boston, MA, USA) in $1 \times \mathrm{HF}$ buffer. Each $50 \mu 1$ reaction contained $0.5 \mathrm{mM}$ dNTP and $1 \mu \mathrm{M}$ of primers. The PCR conditions consisted of an initial denaturation step of $30 \mathrm{~s}$ at $98^{\circ} \mathrm{C}$, followed by 35 cycles of $10 \mathrm{~s}$ at $98^{\circ} \mathrm{C}, 15 \mathrm{~s}$ at $55^{\circ} \mathrm{C}$ and $15 \mathrm{~s}$ at $72^{\circ} \mathrm{C}$, and a final extension step at $72^{\circ} \mathrm{C}$ for $5 \mathrm{~min}$. The sequencing was performed at Macrogen Inc., Korea, using the FLX 454 (454 Life Sciences, Branford, CT, USA). 


\subsection{Real-Time Quantitative PCR}

Bacterial 16S rRNA genes were quantified by qPCR with LightCycler ${ }^{\circledR} 480$ SYBR Green I $2 \times$ Master mix (Roche, Finland) using primers P1 and P2 [29]. Reactions were performed in triplicate for each sample. Each reaction contained $1 \mu \mathrm{l}$ of extracted DNA as template and 5 pmol of both forward and reverse primers. The qPCR was performed on a Roche LightCycler 480 (Roche Applied Science, Germany) on white 96-well plates (Roche Applied Science, Germany). The qPCR conditions consisted of an initial denaturation at $95^{\circ} \mathrm{C}$ for 10 minutes followed by 45 amplification cycles of 15 seconds at $95^{\circ} \mathrm{C}, 30$ seconds at $55^{\circ} \mathrm{C}$ and 30 seconds at $72^{\circ} \mathrm{C}$ with a quantification measurement at the end of each elongation. A final extension step of three minutes at $72^{\circ} \mathrm{C}$ was performed prior to a melting curve analysis. This consisted of a denaturation step for 10 seconds at $95^{\circ} \mathrm{C}$ followed by an annealing step at $65^{\circ} \mathrm{C}$ for one minute prior to a gradual temperature rise to $95^{\circ} \mathrm{C}$ at a rate of $0.11^{\circ} \mathrm{C} \mathrm{s}^{-1}$ during which the fluorescence was continuously measured. The number of bacterial 16S rRNA genes was determined by comparing the amplification result $(\mathrm{Cp})$ to that of a dilution series of $E$. coli 16S rRNA genes in plasmid.

\subsection{Sequence Processing and Analysis}

Sequence reads were analysed using QIIME [31] to remove adapter, barcode and primer sequences, and to exclude sequences that did not meet the quality criteria (i.e., no barcode and primer mismatches, no ambiguous nucleotides, maximum eight nucleotide long homopolymer stretches and defined minimum length of $200 \mathrm{bp}$ ). The bacterial 16S rRNA genes sequences were grouped into Operational Taxonomic Units (OTUs; 97\% sequence similarity) and classified using the GreenGenes 13_8 16S rRNA gene sequence reference database [32]. The sequencing coverage was evaluated by rarefaction analysis and the estimated species richness and diversity indices were calculated. For comparable $\alpha$ - and $\beta$-diversity analyses the data sets were normalized by random subsampling of 1147 sequences/sample. Samples with lower number of sequences were excluded. Microbial metabolic pathways were estimated based on the 16S rRNA gene data using the PICRUSt software [33] on the web based Galaxy application [34]-[36].

\subsection{Accession Numbers}

The sequences have been submitted to the European Nucleotide Archive (http://www.ebi.ac.uk/ena) under accession numbers ERS515436 - ERS515450.

\subsection{Statistical Analyses}

The relationships between the measured peat characteristics, amount of bacteria, community richness (Chao 1) and diversity (Shannon index H') of the bacterial community, and bacterial community structure, were analysed by univariate analysis. Prior to the analysis the normal distribution of the data was evaluated by the Shapiro-Wilk test $(\mathrm{p}<0.05)$. Hypotheses about normality were rejected for $\mathrm{pH}$, moisture, organic matter content, Shannon index and the abundance of taxonomic groups. Only richness (Chao 1) was close to normal distribution. Therefore, we used Spearman's correlation analysis, since the Spearman's rank correlation coefficient does not assume that the relationship among the variables is linear. All statistical analyses were performed using OriginPro 8.6 (OriginLab, USA).

\section{Results and Discussion}

\subsection{Characteristics of the Surface, Peat and Clay Samples}

The humification degree of the peat samples increased as a function of depth from $\mathrm{H} 3$ in the $0.5-1.0 \mathrm{~m}$ layer to H4 - H5 in the middle layers and finally to H6 in the deepest peat layer at $5.5-6.0 \mathrm{~m}$ (Table 1). The deepest sampling layer $(6.5-7.0 \mathrm{~m})$ below the peat layers was light grey clay. The organic matter $(\mathrm{OM})$ content of the samples was measured by the loss on ignition (LOI) method, and although the OM content and LOI are not exactly the same they strictly correlate with each other. For simplicity, here we refer to LOI as OM content. The OM content was relatively constant, $99.6 \% \pm 0.2 \%$ on average, down to the depth of $4.0 \mathrm{~m}$ and decreased to $95.0 \% \pm 0.2 \%$ at $5.5-6.0 \mathrm{~m}$. The OM content of the deepest (clay) layer was $15.3 \%$. Water content of the peat ranged from $66.2 \%$ to $92.7 \%$. Water content was lowest in the $2.5-3.0 \mathrm{~m}$ peat layer of the bog. The $\mathrm{pH}$ of the bog 
Table 1. Characteristics of the peat sample obtained from different depths in Lastensuo bog.

\begin{tabular}{ccccc}
\hline Layer & $\mathrm{pH}^{*}$ & Humification degree & Water content, $\%$ & Organic matter content* $\%$ \\
\hline $0 \mathrm{~m}$ (surface) & 3.1 & $\mathrm{H} 1$ & 92.0 & 99.2 \\
$0.5-1.0 \mathrm{~m}$ & 3.1 & $\mathrm{H} 3$ & 88.8 & 99.5 \\
$1.5-2.0 \mathrm{~m}$ & 3.0 & $\mathrm{H} 4$ & 90.9 & 99.6 \\
$2.5-3.0 \mathrm{~m}$ & 3.2 & $\mathrm{H} 4$ & 66.2 & 99.8 \\
$3.5-3.7 \mathrm{~m}$ & 3.2 & $\mathrm{H} 4 / \mathrm{H} 5$ & 94.1 & 99.8 \\
$3.7-4.0 \mathrm{~m}$ & 3.3 & $\mathrm{H} 5$ & 91.0 & 99.8 \\
$5.5-6.0 \mathrm{~m}$ & 4.0 & $\mathrm{H} 6$ & 83.3 & 95.0 \\
$6.5-7.0 \mathrm{~m}$ & 5.3 & Clay & 73.2 & 15.3 \\
\hline
\end{tabular}

${ }^{*} \mathrm{pH}$ was measured in $0.01 \mathrm{M} \mathrm{CaCl}_{2}$ solution; ${ }^{* *}$ Organic matter was determined by loss on ignition (LOI) method.

was approximately the same, $3.1-3.3$, to the depth of $3.5-4.0 \mathrm{~m}$ and increased to 4.0 and 5.3 at depths of 5.5 $6.0 \mathrm{~m}$ and $6.5-7.0 \mathrm{~m}$, respectively.

\subsection{Microbial Counts-qPCR}

The number of bacterial 16S rRNA gene copies determined by qPCR was used as a proxy for estimating the size of the bacterial community at different depths in the bog. The 16S rRNA gene copy number is not a precise indicator of bacterial population size because different bacterial species contain varying numbers of 16S rRNA gene copies in their genomes. However, here we assumed that the bacteria inhabiting this oligotrophic environment are slow growing organisms with only a low number of 16S rRNA genes in their genomes. The obtained gene copy number is, thus, used as a proximation for bacterial number. All peat samples except that from 2.5 $3.0 \mathrm{~m}$ depth had similar numbers of bacterial 16S rRNA genes: $1 \times 10^{10}-5 \times 10^{10}$ copies $^{-1}$ dry weight (DW) peat. The lowest bacterial numbers were detected in the peat sample from the $2.5-3.0 \mathrm{~m}$ depth $\left(2 \times 10^{9}\right.$ copies $\left.\mathrm{g}^{-1} \mathrm{DW}\right)$ and the clay layer $\left(5 \times 10^{9}\right.$ copies $\left.\mathrm{g}^{-1} \mathrm{DW}\right)$.

\subsection{Bacterial Community Composition and Diversity}

HTP sequencing of bacterial 16S rRNA genes with 454 technologies identified a total of 12,680 bacterial Operational Taxonomic Units (OTUs) sharing 97\% internal sequence homology. The highest number of OTUs in the normalized data was observed at $0 \mathrm{~m}$ with 488 identified and up to 1143 estimated (Chao 1) bacterial OTUs (Table 2). This sample also had the highest diversity index $\left(\mathrm{H}^{\prime}=8.28\right.$, normalized to equal number of reads/ sample). In general, the lowest number of identified $(<200)$ and estimated OTUs $(<600)$ and diversity index $(<6)$ was shown in samples between 1.5 to $4 \mathrm{~m}$ depth, with the exception of one of the parallel samples from $2.5-3.0$ $\mathrm{m}$, which had a slightly higher number of identified OTUs. The rarefaction analyses showed that bacterial community was quite well characterized (Figure S1). However, the non-normalized sequence data showed that $>70 \%$ of the diversity was in general obtained from the uppermost $(0 \mathrm{~m})$ and the deepest $(5.5-7.0 \mathrm{~m}) \mathrm{sam}$ ples, with the exception of one of the parallel samples from $1.5-2.0 \mathrm{~m}$ and $2.5-3.0 \mathrm{~m}$, for which $<70 \%$ of the diversity was obtained by the HTP sequencing.

A total of 40 different bacterial phyla of which 13 phyla were present at all depths were detected (Figure 1). These phyla covered $97 \%$ - $99 \%$ of all sequence reads of each sample. A detailed heat map showing the relative abundance of the detected genera is presented in the supplementary material (Table S1). On the surface, the microbial community was dominated by acidophilic Acidobacteria (Subdivisions 1 and 3), $\alpha$ - and $\gamma$-Proteobacteria (Acetobacteraceae and Sinobacteraceae). Plantomycetes, candidate division WPS-2 and Verrucomicrobia were also detected in the $0 \mathrm{~m}$ sample. Acidobacteria clearly dominated the bacterial community in the peat layers between $0.5 \mathrm{~m}$ and $3.7 \mathrm{~m}$ and remained the most abundant phylum between $3.7 \mathrm{~m}$ and $6.0 \mathrm{~m}$, although their relative abundance decreased below $50 \%$ at this depth. The relative amount of proteobacterial sequences in the peat declined significantly with depth, but increased again in the clay layer. In subsurface peat, the Proteobacteria accounted for only $0.9 \%-11.7 \%$ of the bacterial community showing the lowest abundance at $2.5-3.7 \mathrm{~m}$ 


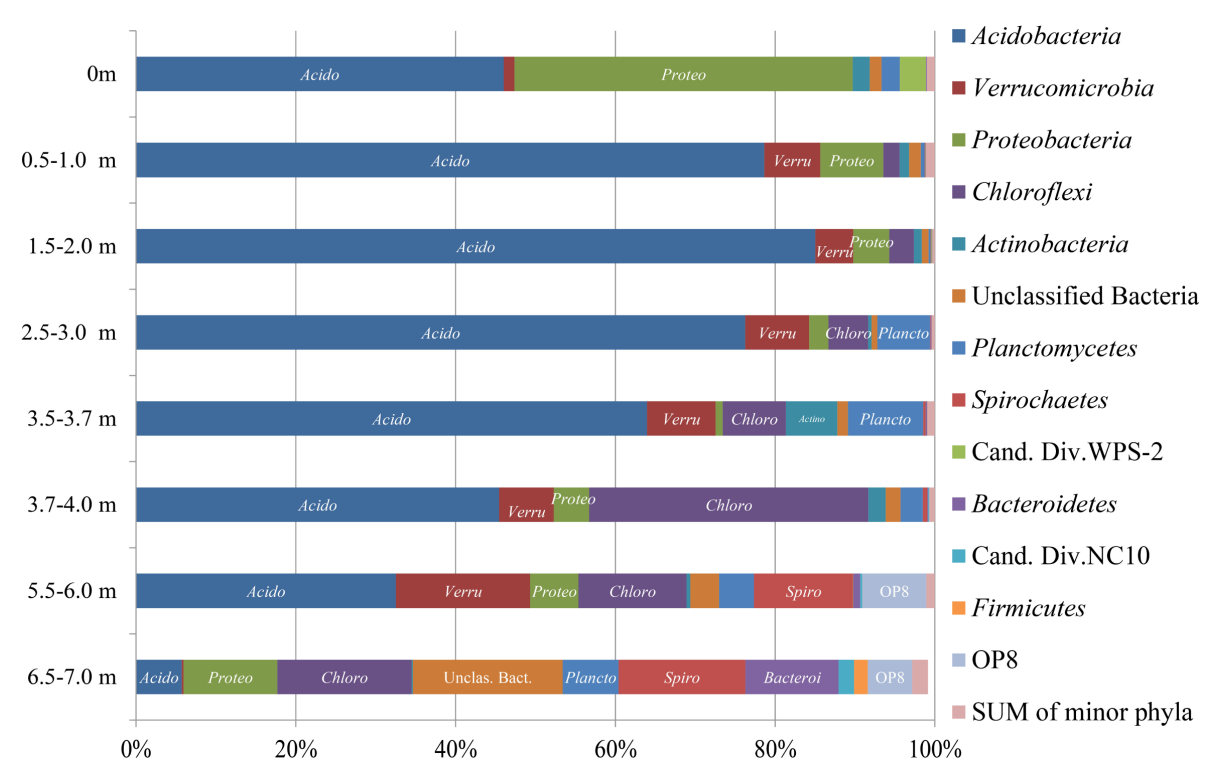

Figure 1. Relative distribution of dominant phyla in samples collected from eight different depths. Operational Taxonomic Units (OTUs) are defined at $97 \%$ sequence identity threshold. "Sum of minor phyla" designates the combined relative sequence abundance of those phyla and candidate taxa which present $<1.0 \%$ in any sample. Minor groups: phyla-Armati- monadetes, Chlorobium, Lentisphaerae, Nitrospirae, Fibrobacteres, Elusimicrobia, Cyanobacteria, Gemmatimonadetes, and Caldiserica; candidate divisions-AC1, AD3, BRC1, FCPU426, GN04, GOUTA4, NKB19, TM7, OD1, OP1, OP3, OP11, SC4, TM6, WS1, WS2, WS3 and WS4.

Table 2. Observed species richness and diversity estimates from high throughput sequencing analysis (97\% Operational Taxonomic Unit, OTU, similarity).

\begin{tabular}{|c|c|c|c|c|c|c|c|c|c|c|c|}
\hline Depth & Sample & $\begin{array}{l}\text { Number } \\
\text { of } \\
\text { sequence } \\
\text { reads }\end{array}$ & $\begin{array}{c}\text { Observed } \\
\text { number } \\
\text { of OTUs }\end{array}$ & $\begin{array}{c}\text { Estimated } \\
\text { number } \\
\text { of OTUs } \\
\text { Chao } 1\end{array}$ & $\begin{array}{r}\begin{array}{r}\text { Dive } \\
\text { estim }\end{array} \\
\text { Shannon }^{*}\end{array}$ & $\begin{array}{l}\text { rrsity } \\
\text { lators } \\
\text { Simpson }\end{array}$ & $\begin{array}{c}\text { OTUs } \\
\text { consisting } \\
\text { of single } \\
\text { sequences" }\end{array}$ & $\begin{array}{c}\text { OTUs } \\
\text { consisting } \\
\text { of double } \\
\text { sequences" }\end{array}$ & $\begin{array}{c}\text { Observed } \\
\text { number } \\
\text { of OTUs, } \\
\text { total }\end{array}$ & $\begin{array}{c}\text { Estimated } \\
\text { number } \\
\text { of OTUs, } \\
\text { total } \\
\text { Chao } 1\end{array}$ & $\begin{array}{c}\text { Diversity } \\
\text { obtained from } \\
\text { all } \\
\text { sequences, } \\
\%\end{array}$ \\
\hline \multirow{2}{*}{$0 \mathrm{~m}$} & $\mathrm{a}$ & 3799 & 485 & 980 & 8.28 & 0.99 & 289 & 83 & 877 & 1161 & 75.6 \\
\hline & $\mathrm{b}$ & 10,822 & 488 & 1143 & 8.20 & 0.99 & 314 & 74 & 1275 & 1369 & 93.2 \\
\hline \multirow{2}{*}{$0.5-1 \mathrm{~m}$} & $\mathrm{a}$ & 3621 & 351 & 924 & 6.95 & 0.98 & 235 & 47 & 686 & 1103 & 62.2 \\
\hline & $\mathrm{b}$ & 12,545 & 299 & 628 & 6.52 & 0.96 & 180 & 48 & 1149 & 1677 & 68.5 \\
\hline \multirow{2}{*}{$1.5-2 \mathrm{~m}$} & $\mathrm{a}$ & 45,647 & 190 & 541 & 5.17 & 0.92 & 122 & 20 & 1830 & 2346 & 78.0 \\
\hline & $\mathrm{b}$ & 11,861 & 157 & 420 & 4.84 & 0.91 & 95 & 16 & 629 & 1109 & 56.7 \\
\hline \multirow{2}{*}{$2.5-3 \mathrm{~m}$} & $\mathrm{a}$ & 10,177 & 185 & 465 & 5.66 & 0.96 & 109 & 20 & 671 & 1084 & 61.9 \\
\hline & $\mathrm{b}$ & 21,238 & 215 & 514 & 5.98 & 0.96 & 130 & 27 & 1089 & 1460 & 74.6 \\
\hline \multirow{2}{*}{$3.5-3.7 \mathrm{~m}$} & $\mathrm{a}$ & 30 & & & & & & & 19 & 32 & 59.0 \\
\hline & $\mathrm{b}$ & 6442 & 183 & 523 & 5.53 & 0.95 & 108 & 16 & 469 & 795 & 59.0 \\
\hline \multirow{2}{*}{$3.7-4 \mathrm{~m}$} & a & 1147 & 172 & 327 & 5.04 & 0.90 & 92 & 26 & 172 & 327 & 52.6 \\
\hline & $\mathrm{b}$ & 7768 & 177 & 372 & 4.76 & 0.86 & 103 & 26 & 5080 & 780 & 65.1 \\
\hline \multirow{2}{*}{$5.5-6 \mathrm{~m}$} & a & 7698 & 281 & 568 & 6.50 & 0.97 & 168 & 48 & 814 & 1158 & 70.3 \\
\hline & $\mathrm{b}$ & 13,426 & 272 & 739 & 6.39 & 0.97 & 176 & 32 & 1073 & 1391 & 77.1 \\
\hline \multirow{2}{*}{$6.5-7 \mathrm{~m}$} & $\mathrm{a}$ & 4359 & 355 & 682 & 7.26 & 0.98 & 202 & 61 & 655 & 801 & 81.7 \\
\hline & $\mathrm{b}$ & 7455 & 340 & 633 & 7.04 & 0.98 & 194 & 63 & 764 & 851 & 89.8 \\
\hline
\end{tabular}

" ${ }^{*}$ ormalized to 1147 sequences: a-DNA sample obtained by extraction with the buffer SL1; b-DNA sample obtained by extraction with the buffer SL2. 
depth. The phylum Chloroflexi was not detected in the surface sample, but was abundant in the deep peat and bottom clay layers, with highest representation at $3.7-4.0 \mathrm{~m}$ (34.9\%). The phylum Planctomycetes was present throughout the depth profile, although its relative amount in the peat between 0.5 and $2.0 \mathrm{~m}$ was less than $1.0 \%$. The highest relative abundance of Planctomycetes was detected at $2.5-3.7 \mathrm{~m}$ depth $(6.6 \%-9.4 \%)$. Actinobacteria were also detected in all samples with a maximum relative abundance from $3.5-3.7 \mathrm{~m}$ depth $(6.5 \%)$.

The highest bacterial diversity was obtained from the peat at $5.5-6.0 \mathrm{~m}$ and the former seabed clay at 6.5 $7.0 \mathrm{~m}$. In the peat Acidobacteria (32.5\%), Verrucomicrobia (16.8\%), Chloroflexi (13.5\%), Spirochaetes (12.4\%), OP8 (8.0\%), Proteobacteria (6.0\%), and Planctomycetes (4.4\%) were the dominating phyla. The bacterial community in the clay was represented by Chloroflexi $(16.8 \%)$, Spirochaetes $(15.9 \%)$, Proteobacteria $(11.8 \%)$, Bacteroidetes (11.7\%), Planctomycetes $(7.0 \%)$ and Acidobacteria $(5.72 \%)$. In addition, the bacterial sequences that could not be assigned to any known bacterial phyla were present at high numbers $(18.8 \%)$.

\subsection{Correlation of Bacterial Community and Bog Core Characteristics}

Correlation analysis (Table S2) showed that the copy number of 16S rRNA genes had a significant positive correlation with $\mathrm{OM}(\mathrm{r}=0.86 ; \mathrm{p}<0.01)$ content, and negative with $\mathrm{pH}(\mathrm{r}=-0.5 ; \mathrm{p}<0.05)$. Bacterial richness (based on Chao 1 estimator) and diversity (Shannon index) correlated only with OM content.

Only phylum Actinobacteria showed positive relationship with water content of the samples. Nevertheless, ten phyla or classes correlated with $\mathrm{pH}$ and four phyla or classes with OM content (Table S3). The peat samples had very low $\mathrm{pH}$ ranging from 3.1 in the surface sample to $\mathrm{pH} 4.0$ in the deepest (5.5 - $6.0 \mathrm{~m}$ below the surface) peat sample, while the bottom clay layer had $\mathrm{pH} 5.3$. Low $\mathrm{pH}$ most probably served as an ecological filter and the absence of the correlation between the $\mathrm{pH}$ and many taxonomic groups was due to the small variations in $\mathrm{pH}$ between the samples. Acidobacterial TM1, the largest group in all subsurface peat samples, except in layer 3.7 $4.0 \mathrm{~m}$, did not correlate with $\mathrm{pH}$, water or OM content. The class Dehalococcoidetes (GIF9), dominating the whole bacterial community in the sample collected from $3.7-4.0$ m showed only positive relationship with pH. The distribution of phylum Verrucomicrobia did not correlate with any measured parameters.

\subsection{Characteristics of the Major Phyla}

Acidobacteria The phylum Acidobacteria was represented by several subdivisions (Figure 2(A)). On the surface $(0 \mathrm{~m})$, the most prominent lineage was the Subdivision 1 (class Acidobacteria) followed by Subdivision 3 (class Solibacteres). The phylum Acidobacteria is a large diverse group consisting of at least 26 subdivisions [37], but few isolated and characterized species exist. Their ecological role in elemental cycles, thus, is poorly understood. The isolated members of this group are aerobic or facultative anaerobic organisms. The prevalence of Acidobacteria, especially Subdivisions 1, 2 and 3, in acidic low-nutrient Sphagnum peat has been documented [23] [24] [38]. The majority of the acidobacterial Subdivision 1 sequences from the Lastensuo Bog could not be assigned to any known genus. The genus Granulicella was detected in all peat layers with relative abundance ranging from $2 \%$ of total bacterial community in the surface samples to $<0.5 \%$ at $3.7-6.0 \mathrm{~m}$. Members of this genus have been isolated from tundra soil and Sphagnum peat of bogs [39] [40]. Acidobacterial Subdivision 1 has an important role in degradation of cellulose in acidic Sphagnum peat [41]. This is supported by a complete genomic analysis of two cultured strains of Subdivision 1 [42]. Cellulolytic bacteria have recently been isolated from Sphagnum peat samples and characterized [43]. Genomic analyses also suggested that the Acidobacteria play a role in nitrogen cycling in soils and sediments with ability for nitrate and nitrite reduction [42]. As this microbial group was dominant in the Lastensuo Bog peat, it may, in addition to contributing to the carbon cycle and the degradation of dead plant biomass, also be the major nitrogen cycling bacterial group in this community.

Sequences assigned to Subdivision 3 (Candidatus Solibacter) accounted for almost 34\% of all acidobacterial sequences in the moss layer. Their relative amount declined with depth, except for the samples from $2.5 \mathrm{~m}$ to 3.7 $\mathrm{m}$, where they accounted for about $20 \%$ of all acidobacterial sequences.

In this study we found that an uncultured group represented by a cloned 16S rRNA gene sequence obtained from grass roots, clone TM1 [44], was the most abundant acidobacterial group in all subsurface peat samples as well as in the clay layer accounting for up to $59.8 \%$ of the total sequence number retrieved from $1.5-2.0 \mathrm{~m}$ depth. To the best of our knowledge, there are no reports on such high abundance of this group in acidic peat bogs. Acidobacterial Subdivision 2 was mostly detected in the middle of the peat core collected from $3.5 \mathrm{~m}$ to $4.0 \mathrm{~m}$ depth. Sequences assigned to class Holophagae (Subdivision 8) as well as those represented by several uncultivated clones MVS-40 and OS-K were found only in small amounts. 


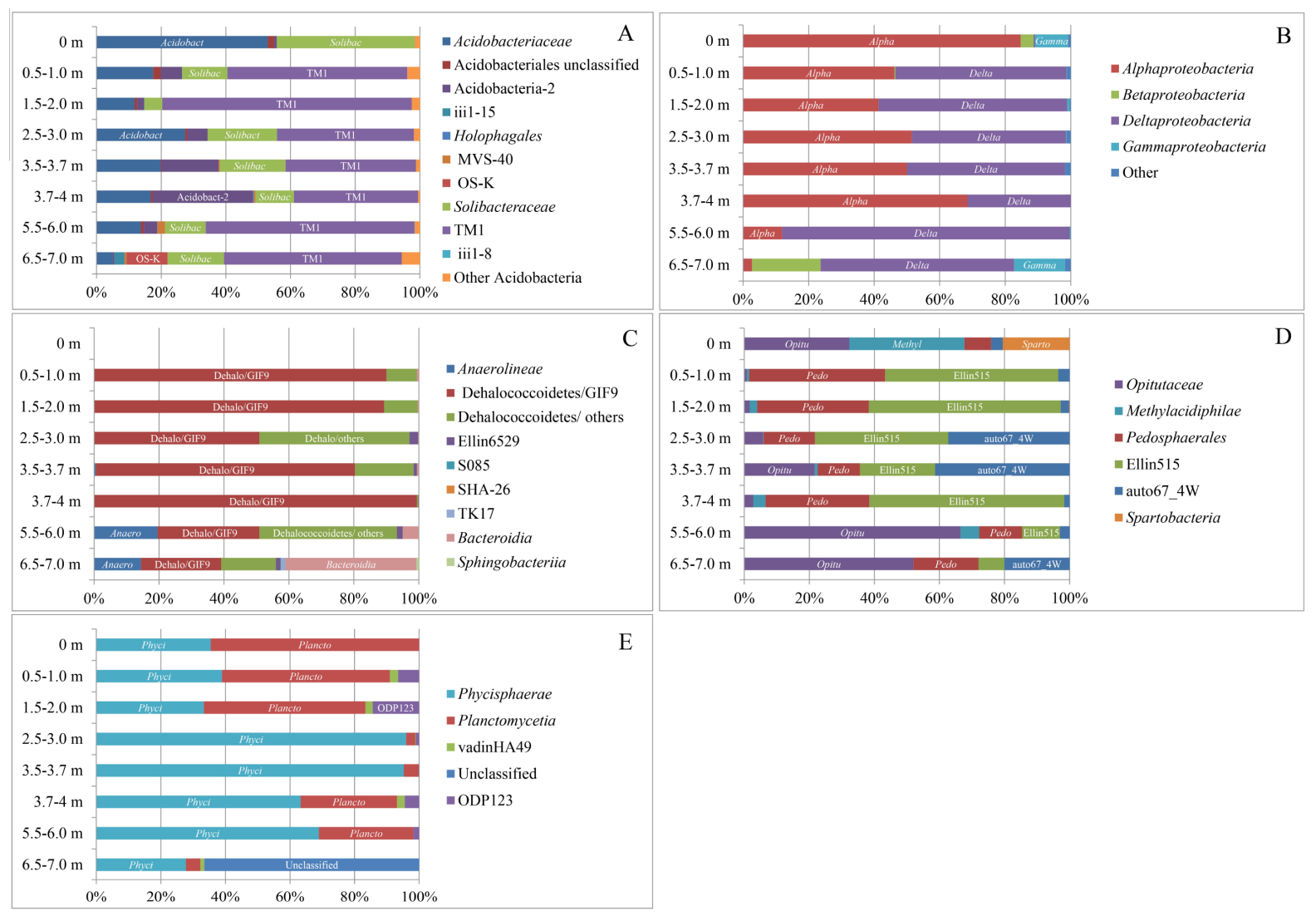

Figure 2. Diversity of the phyla in peat samples in relation to depth: A-Acidocabteria; B-Proteobacter; C-ChloroflexiBacteroides lineage; D-Verrucomicrobia; E-Planctomycetes.

Proteobacteria The Proteobacteria were primarily represented by $\alpha$-proteobacterial lineages at depths from the surface to $4.0 \mathrm{~m}$ (Figure 2(B)). The diversity of $\alpha$-Proteobacteria was high. In the moss layer, the major group was unclassified Acetobacteraceae (about 20\% of the total community). Representatives of this group inhabit various acidic environments and have often been found in acidic peat [24] [38] [45]-[47]. The family Methylocystaceae was present at notable relative abundance in the moss layer (more than 3\% of all bacterial sequences) but was also detected in all peat layers and the bottom clay. These bacteria are generally aerobic methanotrophic organisms oxidizing methane emitted from deeper peat layers before it reaches the atmosphere [48]. Nevertheless, as shown for Methylocystis parvus, they are able to succeed under anoxic conditions by fermenting a storage compound, poly- $\beta$-hydroxybutyrate as an alternative to aerobic methane oxidation [49].

$\beta$-Proteobacteria were only detected in the moss layer and in the clay from $6.5-7.0 \mathrm{~m}$ depth, where they were the second largest proteobacterial group. All $\beta$-proteobacterial sequences found in the clay were grouped to the family Comamonadaceae, which was mostly represented by the genus Hydrogenophaga, harbouring mostly hydrogen-oxidizing chemoautotrophic microorganisms (1.8\% of the total sequence reads).

$\delta$-Proteobacteria were present in the moss layer at only very low abundance. However, their abundance in regard to the other proteobacterial classes increased with depth. In all subsurface samples this lineage was the main proteobacterial group, accounting for more than $80 \%$ of all Proteobacteria at $5.5-6.0 \mathrm{~m}$. The majority of $\delta$-Proteobacteria at $0.5-1.0 \mathrm{~m}$ depth was affiliated with the anaerobic acetate-degrading sulphate reducing genus Desulfobacca [50]. In the clay layer the $\delta$-Proteobacteria were mostly represented by genus Syntrophus, members of which are strict anaerobes living in syntrophic relationship with hydrogen- and formate-utilizing microorganisms [51] such as Hydrogenophaga. 16S rRNA gene sequences belonging to Syntrophus sp. have recently been retrieved from acidic bog peat [38] [52] [53]. Sequences of uncultured $\delta$-Proteobacteria similar to those represented by the environmental clone BPC076 (Accession Number AF154096) originating from a hydrocarbon seep were detected only in peat from $5.5-6.0 \mathrm{~m}$ depth and clay where they represented $62 \%$ and $37 \%$, respectively, of all $\delta$-proteobacterial sequences found in these layers. 
$\gamma$-Proteobacteria were detected in the moss layer and clay and were not found in the peat between $3.5 \mathrm{~m}$ and $4.0 \mathrm{~m}$ depth. In the surface sample more than $90 \%$ of the $\gamma$-proteobacterial sequences were affiliated with the order Xanthomonadales (4.1\% of the total community) and in the clay to methanotrophic Methylococcales $(1.8 \%)$, almost entirely represented by the genus Crenothrix (1.8\% of the total bacterial community). Surprisingly, the latter was retrieved only from the sample from $6.5-7.0 \mathrm{~m}$. The isolated members of this genus are aerobic methane oxidizing bacteria [54]. Recent discovery of a new form of fermentation-based methanotrophy in Methylomicrobium alcaliphilum, however, opened the possibility that under anoxic conditions methanotrophs are capable of methane consumption with production of hydrogen [55]. Whether such metabolic activity exists in other Methylococcales species is yet to be shown.

Chloroflexi-Bacteroidetes lineage Chloroflexi were absent from the moss layer but present in all subsurface samples (Figure 2(C)). They were the second largest bacterial group (34.9\%) in the peat from $3.7-4.0 \mathrm{~m}$ depth. In all subsurface samples to the depth of $4.0 \mathrm{~m}$, Chloroflexi were represented almost entirely by the class Dehalococcoidetes, from $97 \%$ to $100 \%$ of all chloroflexi sequences. The majority of the Dehalococcoides sequences were assigned to candidate group GIF9 originally isolated from a chlorobenzene contaminated groundwatertreated reactor [56]. Members of the class Dehalococcoidetes so far isolated and physiologically characterized are anaerobic obligate organohalide-respiring microorganisms that use hydrogen as an electron acceptor [57] [58]. The appearance of these bacteria might be connected to the accumulation of halogenated organic compounds as a result of humification of plant material [59]. Currently, however, there is no evidence to conclude that the metabolism of group GIF9 would be as unusual as it is for the isolated Dehalococcoides species. The lineage Anaerolineae appeared only in the deepest peat collected from $5.5-6.0 \mathrm{~m}$ and the clay. Members of the Anaerolineae are filamentous anaerobic bacteria, which have been identified from diverse environments, including arctic permafrost, sediments, and anaerobic methanogenic sludge bioreactors [60]-[62]. Characterized Anaerolineae strains are able to ferment carbohydrates [63]. In addition, some Anaerolineae species have been found to benefit from syntrophic relationships with hydrogenotrophic methanogens.

The phylum Bacteroidetes was almost entirely represented by a taxonomically unclassified group of the order Bacteroidales (Figure 2(C)). The isolated and characterized members of this group are mostly anaerobic or facultative anaerobic microorganisms found in a large variety of environments, from sediment to biogas reactors [64]. A nitrogen-fixing facultative anaerobe, which belongs to this order, was also recently characterized [65].

Verrucomicrobia Verrucomicrobial sequences were assigned to four classes, namely, Opitutae, Pedosphaerae, Methylacidiphilae and Spartobacteria, of which the two last groups are present only in a few of the tested samples and only at very low abundance levels (Figure 2(D)). The majority of the verrucomicrobial sequences belonged to the class Pedosphaerae, which were most abundant in subsurface peat layers. Sequences assigned to the subdivision 4 (class Opitutae) were retrieved from all depths, with the exception of the surface sample. The majority of the sequences formed an unknown group of the family Opitutaceae. This group was abundant in the peat layer from 5.5 to $6.0 \mathrm{~m}$ depth where it accounted for more than $11 \%$ of the total bacterial community. Verrucomicrobial Subdivision 4 was reported from an acidic peat bog [24] [38]. However, unlike in our study it was abundant only in surface samples. Bacteria from this family are known to be fermentative anaerobes [66] and to have the ability to degrade lignocellulose and fix nitrogen [67]. The abundance of the class Pedosphaerae was uniform in the layers from $0.5 \mathrm{~m}$ to $6.0 \mathrm{~m}$ depth. In the moss layer and deepest clay layer this group was minor. The majority of pedosphaerael sequences remained unassigned to any known Pedosphaerae group, but was closely similar to a group of uncultured Pedosphaerae represented by clone Ellin515 obtained from soil [68]. Sequences assigned to the sub-phylum 6, i.e., class Methylacidiphilae, which is currently known to contain only methanotrophs [16] [69], were detected in all samples, but were present at low abundance.

Planctomycetes Planctomycetes bacteria were present at all depths, but in the peat at $0.5-2.0 \mathrm{~m}$ depth, they were present at very low abundance (Figure 2(E)). In the peat layer from $2.5 \mathrm{~m}$ to $6.0 \mathrm{~m}$ depth the Planctomycetes were mostly represented by the Phycisphaerae lineage, which accounted for almost $9 \%$ of the total community in peat from $3.5-3.7 \mathrm{~m}$. The Phycisphaerae have recently been isolated from marine algae [70]. The pure cultured species of this group are facultative anaerobes able to reduce nitrate to nitrite. In addition, the Phycisphaerae species heterotrophic, with the ability to hydrolyse different sugars and organic acids. In the clay layer at $6.5-7.0 \mathrm{~m}$ sequences affiliated with unclassified Planctomycetes were predominant (4.6\%). Planctomycetes isolated from acidic peat available in pure culture are aerobic or facultative anaerobic chemoorganoheterotrophic bacteria [71]-[74]. However, certain members of the Planctomycetes are able to perform the ANAMMOX process, i.e., the anaerobic oxidation of ammonia to $\mathrm{N}_{2}$ gas [75]. 
Spirochaeta The role of Spirochaeta in acidic peatland environment is unclear. Some members of this genus are sulphur- and thiosulphate-reducers. However, these bacteria are more often associated with high $\mathrm{pH}$. Genes encoding nitrogenase enzymes (used in nitrogen fixation), closely related to those from Spirochaeta have been detected in a bacterial community associated with Sphagnum moss [76].

Candidate Divisions Among the detected candidate divisions the three most abundant ones were NC10, OP8, and WPS-2. Sequences assigned to the candidate division OP8 (current name Aminicenantes) were not found in the samples above $4.0 \mathrm{~m}$, but they were abundant in the peat samples collected from $5.5-6.0 \mathrm{~m}$ and the clay from $6.5-7.0 \mathrm{~m}$ below the surface $(8.0 \%$ and $5.6 \%$ of the total, respectively). This division was established based on sequences found from hot spring [77]. In silico database mining has shown that this phylogenetically diverse group is ubiquitous, found in different environmental niches, although more often in anoxic low salinity environments [78]. To our knowledge this is the first report of this group recovered from an acidic bog.

Candidate division NC10 was also absent in the surface samples, appearing only at relative low abundance level (less than $0.05 \%$ ) from $1.5-3.0 \mathrm{~m}, 3.7-4.0 \mathrm{~m}$ and $5.5-6.0 \mathrm{~m}$, but accounted for $1.9 \%$ of the total community in the clay at $6.5-7.0 \mathrm{~m}$. This group harbours the denitrifying methanotrophic organism "Candidatus Methylomirabilis oxyfera" [79], which performs nitrite-dependent anaerobic methane oxidation in anaerobic environments [80]. Sequences affiliated with candidate division WPS-2 were present in the surface sample with relative abundance $3.3 \%$, but were also recovered at very small amounts from all subsurface samples, less than $0.05 \%$ of the total community. This division has also previously been seen in acidic peat of northern wetland [24].

\subsection{Predicted Metabolic Pathways of the Bacterial Community}

The metabolic pathways presented in the bacterial community at different depths of the sample core were predicted based on the 16S rRNA gene data using the recently developed software PICRUSt [33]. The most abundant metabolic pathways contributing $>1 \%$ of the predicted genes in the bacterial community are presented in Figure 3. The accuracy of the metabolic estimator depends on quantity and quality of annotated genomes. Because of the large proportion of poorly described taxa in the Lastensuo Bog samples, the metabolic profiling can be biased and needs to be updated when new genome sequences are annotated. Nevertheless, this approach gave us additional information on the bacterial community. Little variation in the predominant metabolic pathways was observed between the different depths. However, the clay layer at the bottom showed a slightly different pattern than the moss and peat samples. The carbon fixation, nitrogen metabolism, oxidative phosphorylation, sulphur metabolism, amino sugar and nucleotide sugar metabolism, starch and sucrose metabolism, peptidases and specific secretion systems showed the lowest representation in the clay compared to the moss and peat samples. The clay layer had the highest representation of purine metabolism, pyrimidine metabolism, glycolysis/gluconeogenesis, pyruvate metabolism, glycine and serine and threonine metabolism compared to the moss and peat samples from the various depths. Starch and sucrose metabolism were most abundantly repre- sented in the moss and peat samples, where Acidobacteria was the most common bacterial group. In addition, the relative abundance of methane-metabolizing and nitrogen-cycling bacterial groups identified throughout the peat profile is mirrored by the high predicted number of genes involved in these processes throughout the vertical profile.

\section{Conclusions}

The high throughput sequence analyses revealed a very high diversity within bacterial communities in the sampled acidic peat profile from Lastensuo raised bog. The community was dominated by Acidobacteria, especially the TM1 lineage, which has not been reported for acidic Sphagnum peat before. In addition, many known aerobic methane oxidizing bacterial groups were identified, which might employ alternative metabolic routes for oxidizing methane anaerobically or use completely different life styles under anaerobic conditions. Many nitrogen- and carbon dioxide-fixing bacteria were identified, which could represent primary producers in the anaerobic peat where the majority of the microbial community consisted of OM degraders. In addition to fermentation, nitrate-respiring microorganisms were also frequently detected. The statistical analyses showed that the sample characteristics, such as $\mathrm{pH}$ value, water or OM contents did not influence the bacterial richness or diversity. Additionally, dominant taxonomic groups, such as classes Dehalococcoidetes (GIF9) and acidobacterial TM1 as well as phylum Verrucomicrobia, did not correlate with the above mentioned parameters. The prediction of bacterial metabolic pathways using the PICRUSt software showed that the clay layer differed only slightly from peat or moss samples. 


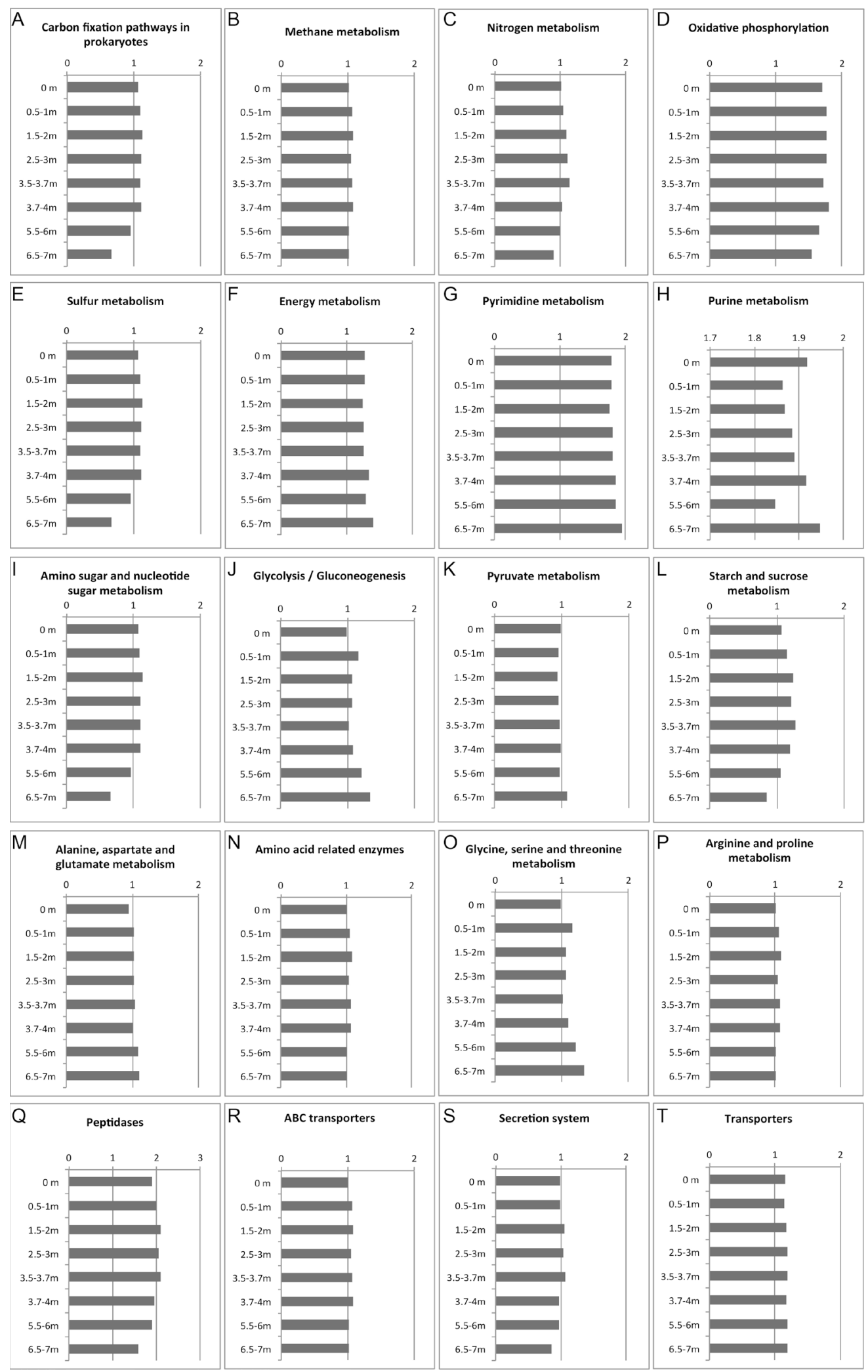

Figure 3. Relative abundance of genes associated with different metabolic activities. From upper left to right: (A)(F) energy metabolism; $(\mathrm{G})-(\mathrm{H})$ nucleotide metabolism; (I)-(L) carbohydrate metabolism; (M)-(P) amino acid metabolism; (Q) enzyme families; (R)-(T) membrane transport. 
The results reported here highlight the necessity for more detailed studies on the Lastensuo Bog characteristics and their effect on bacterial inhabitants. The revealed bacterial community diversity in the acidic ombotrophic Lastensuo Bog can serve as a solid background for further research on bacterial involvement in the fate of radionuclides in case of their release in similar biotopes.

\section{Acknowledgements}

The research project was funded by Posiva Oy and the Academy of Finland. Mirva Pyrhönen is acknowledged for skilful assistance in the laboratory. Dr Brian Gibbson is thanked for language editing and critical comments on the manuscript.

\section{References}

[1] Bridgham, S.D., Megonigal, J.P., Keller, J.K., Bliss, N.B. and Trettin, C. (2006) The Carbon Balance of North American Wetlands. Wetlands, 26, 889-916. http://dx.doi.org/10.1672/0277-5212(2006)26[889:TCBONA]2.0.CO;2

[2] Smith, L.C., Macdonald, G.M., Velichko, A.A., Beilman, D.W., Borisova, O.K., Frey, K.E., Kremenetski, K.V. and Sheng, Y. (2004) Siberian Peatlands a Net Carbon Sink and Global Methane Source Since the Early Holocene. Science, 303, 353-356. http://dx.doi.org/10.1126/science.1090553

[3] Dean, W.E. and Gorham, E. (1998) Magnitude and Significance of Carbon Burial in Lakes, Reservoirs, and Peatlands. Geology, 26, 535-538. http://dx.doi.org/10.1130/0091-7613(1998)026<0535:MASOCB >2.3.CO;2

[4] Turunen, J., Tomppo, E., Tolonen, K. and Reinikainen, A. (2002) Estimating Carbon Accumulation Rate of Undrained Mires in Finland-Application to Boreal and Subarctic Regions. The Holocene, 12, 69-80. http://dx.doi.org/10.1191/0959683602hl522rp

[5] Conrad, R. (2009) The Global Methane Cycle: Recent Advances in Understanding the Microbial Processes Involved. Environmental Microbiology Reports, 1, 285-292. http://dx.doi.org/10.1111/j.1758-2229.2009.00038.x

[6] Virtanen, K. and Valpola, S. (2011) Energy Potential of Finnish Peatlands. In: Nenonen, K. and Nurmi, P.A., Eds., Geoscience for Society, Vol. 125, Geological Survey of Finland, Special Paper 49, Espoo, 153-161.

[7] Coulson, J.C. and Butterfield, J. (1978) An Investigation of the Biotic Factors Determining the Rates of Plant Decomposition on Blanket Bog. Journal of Ecology, 66, 631-650. http://dx.doi.org/10.2307/2259155

[8] Scheffer, R.A., Van Logtestijn, R.S. and Verhoeven, J.T.A. (2001) Decomposition of Carex and Sphagnum Litter in Two Mesotrophic Fens Differing in Dominant Plant Species. Oikos, 92, 44-54. http://dx.doi.org/10.1034/j.1600-0706.2001.920106.x

[9] Posiva (2012) Safety Case for the Disposal of Spent Nuclear Fuel at Olkiluoto-Description of the Disposal System 2012. Report POSIVA 2012-05, Posiva Oy, Eurajoki, 166 p. http://www.posiva.fi/

[10] Mäkiaho, J.P. (2005) Development of Shoreline and Topography in the Olkiluoto Area, Western Finland, 2000 BP8000 AP. Working Report 2005-70, Posiva Oy, Eurajoki, 47 p. http://www.posiva.fi

[11] Haapanen, R., Aro, L., Helin, J., Ikonen, A.T.K. and Lahdenperä, A.M. (2013) Studies on Reference Mires: 1. Lastensuo and Pesänsuo in 2010-2011. Working Report 2012-102, Posiva Oy, Eurajoki.

[12] Posiva (2013) Safety Case for the Disposal of Spent Nuclear Fuel at Olkiluoto-Biosphere Assessment 2012. Report POSIVA 2012-10, Posiva Oy, Eurajoki, 251 p. http://www.posiva.fi/

[13] Haapanen, R., Aro, L., Koivunen, S., Lahdenperä, A.M., Kirkkala, T., Hakala, A., Helin, J. and Ikonen, A.T.K. (2011) Selection of Real-Life Analogues for Future Lakes and Mires at a Repository Site. Radioprotection, 46, S647-S651. http://dx.doi.org/10.1051/radiopro/20116660s

[14] Andersen, R., Chapman, S.J. and Artz, R.R.E. (2013) Microbial Communities in Natural and Disturbed Peatlands: A Review. Soil Biology and Biochemistry, 57, 979-994. http://dx.doi.org/10.1016/j.soilbio.2012.10.003

[15] Dedysh, S.N. (2011) Cultivating Uncultured Bacteria from Northern Wetlands: Knowledge Gained and Remaining Gaps. Frontiers in Microbiology, 2, 184. http://dx.doi.org/10.3389/fmicb.2011.00184

[16] Sharp, C.E., Smirnova, A.V., Graham, J.M., Stott, M.B., Khadka, R., Moore, T.R., Grasby, S.E., Strack, M. and Dunfield, P.F. (2014) Distribution and Diversity of Verrucomicrobia Methanotrophs in Geothermal and Acidic Environments. Environmental Microbiology, 16, 1867-1878. http://dx.doi.org/10.1111/1462-2920.12454

[17] Kip, N., Van Winden, J., Pan, Y., Bodrossy, L., Reichart, G.J., Smolders, A.J.P., Jetten, M.S.M., Sinninghe Damsté, J.S. and Op den Camp, H.J.M. (2010) Global Prevalence of Methane Oxidation by Symbiotic Bacteria in Peat-Moss Ecosystems. Nature Geoscience, 3, 617-621. http://dx.doi.org/10.1038/ngeo939

[18] Juottonen, H., Galand, P.E., Tuittila, E.S., Laine, J., Fritze, H. and Yrjälä, K. (2005) Methanogen Communities and 
Bacteria along an Ecohydrological Gradient in a Northern Raised Bog Complex. Environmental Microbiology, 7, 1547-1557. http://dx.doi.org/10.1111/j.1462-2920.2005.00838.x

[19] Sun, H., Terhonen, E., Koskinen, K., Paulin, L., Kasanen, R. and Asiegbu, F.O. (2014) Bacterial Diversity and Community Structure along Different Peat Soils in Boreal Forest. Applied Soil Ecology, 74, 37-45. http://dx.doi.org/10.1016/j.apsoil.2013.09.010

[20] Morales, S.E., Mouser, P.J., Ward, N., Hudman, S.P., Gotelli, N.J., Ross, D.S. and Lewis, T.A. (2006) Comparison of Bacterial Communities in New England Sphagnum Bogs Using Terminal Restriction Fragment Length Polymorphism (T-RFLP). Microbial Ecology, 52, 34-44. http://dx.doi.org/10.1007/s00248-005-0264-2

[21] Palmer, K., Biasi, C. and Horn, M.A. (2011) Contrasting Denitrifier Communities Relate to Contrasting $\mathrm{N}_{2} \mathrm{O}$ Emission Patterns from Acidic Peat Soils in Arctic Tundra. The ISME Journal, 6, 1058-1077. http://dx.doi.org/10.1038/ismej.2011.172

[22] Lin, X., Green, S., Tfaily, M.M., Prakash, O., Konstantinidis, K.T., Corbett, J.E., Chanton, J.P., Cooper, W.T. and Kostka, J.E. (2012) Microbial Community Structure and Activity Linked to Contrasting Biogeochemical Gradients in Bog and Fen Environments of the Glacial Lake Agassiz Peatland. Applied and Environmental Microbiology, 78, 70237031. http://dx.doi.org/10.1128/AEM.01750-12

[23] Lin, X., Tfaily, M.M., Steinweg, J.M., Chanton, P., Esson, K., Yang, Z.K., Chanton, J.P., Cooper, W., Schadt, C.W. and Kostka, J.E. (2014) Microbial Community Stratification Linked to Utilization of Carbohydrates and Phosphorus Limitation in a Boreal Peatland at Marcell Experimental Forest, Minnesota, USA. Applied and Environmental Microbiology, 80, 3518-3530. http://dx.doi.org/10.1128/AEM.00205-14

[24] Serkebaeva, Y.M., Kim, Y., Liesack, W. and Dedysh, S.N. (2013) Pyrosequencing-Based Assessment of the Bacteria Diversity in Surface and Subsurface Peat Layers of a Northern Wetland, with Focus on Poorly Studied Phyla and Candidate Divisions. PLoS ONE, 8, e63994.

[25] Mäkilä, M. and Grundström, A. (2008) Turpeenikä Ja Kerrostumisnopeuslounais-Suomensoilla. Working Report 2008-12, Posiva Oy, Eurajoki.

[26] Lusa, M., Ämmälä, K., Hakanen, M., Lehto, J. and Lahdenperä, A.M. (2009) Chemical and Geotechnical Analyses of Soil Samples from Olkiluoto for Studies on Sorption in Soils. Working Report 2009-33, Posiva Oy, Eurajoki.

[27] Carter, M.R. and Gregorich, E.G. (2008) Soil Sampling and Methods of Analysis. 2nd Edition, Canadian Society of Soil Science, Taylor \& Francis Group, LLC, Boca Raton.

[28] Edwards, U., Rogall, T., Blöcker, H., Emde, M. and Böttger, E.C. (1998) Isolation and Direct Complete Nucleotide Determination of Entire Genes. Characterization of a Gene Coding for 16S Ribosomal RNA. Nucleic Acids Research, 17, 7843-7853. http://dx.doi.org/10.1093/nar/17.19.7843

[29] Muyzer, G., De Waal, E.C. and Uitterlinden, A.G. (1993) Profiling of Complex Microbial Populations by Denaturing Gradient Gel Electrophoresis Analysis of Polymerase Chain Reaction-Amplified Genes Coding for 16s rRNA. Applied and Environmental Microbiology, 59, 695-700.

[30] Bomberg, M. and Itävaara, M. (2012) The Diversity of Microbial Communities in Olkiluoto Groundwater Fracture Zones Characterized by DNA and RNA Based 16S rRNA-Targeted 454 Pyro Sequencing and qPCR. Posiva Working Report 2012-27, Posiva Oy, Eurajoki.

[31] Caporaso, J.G., Kuczynski, J., Stombaugh, J., Bittinger, K., Bushman, F.D., Costello, E.K., Knight, R., et al. (2010) QIIME Allows Analysis of High-Throughput Community Sequencing Data. Nature Methods, 7, 335-336. http://dx.doi.org/10.1038/nmeth.f.303

[32] Desantis, T.Z., Hugenholtz, P., Larsen, N., Rojas, M., Brodie, E.L., Keller, K., Huber, T., Dalevi, D., Hu, P. and Andersen, G.L. (2006) Greengenes, a Chimera-Checked 16S rRNA Gene Database and Workbench Compatible with ARB. Applied and Environmental Microbiology, 72, 5069-5072. http://dx.doi.org/10.1128/AEM.03006-05

[33] Langille, M.G.I., Zaneveld, J., Caporaso, J.G., Mcdonald, D., Knights, D., Reyes, J.A., Clemente, J.C., Burkepile, D.E., Vega Thurber, R.L., Knight, R., Beiko, R.G. and Huttenhower, C. (2013) Predictive Functional Profiling of Microbial Communities Using 16S rRNA Marker Gene Sequences. Nature Biotechnology, 31, 814-821.

[34] Goecks, J., Nekrutenko, A. and Taylor, J., the Galaxy Team (2010) Galaxy: A Comprehensive Approach for Supporting Accessible, Reproducible, and Transparent Computational Research in the Life Sciences. Genome Biology, 11, R86. http://dx.doi.org/10.1186/gb-2010-11-8-r86

[35] Blankenberg, D., Von Kuster, G., Coraor, N., Ananda, G., Lazarus, R., Mangan, M., Nekrutenko, A. and Taylor, J. (2010) Galaxy: A Web-Based Genome Analysis Tool for Experimentalists. Current Protocols in Molecular Biology, Chapter 19: Unit 19.10.1-21.

[36] Giardine, B., Riemer, C., Hardison, R.C., Burhans, R., Elnitski, L., Shah, P., Zhang, Y., Blankenberg, D., Albert, I., Taylor, J., Miller, W., Kent, W.J. and Nekrutenko, A. (2005) Galaxy: A Platform for Interactive Large-Scale Genome Analysis. Genome Research, 15, 1451-1455. http://dx.doi.org/10.1101/gr.4086505 
[37] Barns, S.M., Cain, E.C., Sommerville, L. and Kuske, C.R. (2007) Acidobacteria Phylum Sequences in UraniumContaminated Subsurface Sediments Greatly Expand the Known Diversity within the Phylum. Applied and Environmental Microbiology, 73, 3113-3116. http://dx.doi.org/10.1128/AEM.02012-06

[38] Dedysh, S.N., Pankratov, T.A., Belova, S.E., Kulichevskaya, I.S. and Liesack, W. (2006) Phylogenetic Analysis and in Situ Identification of Bacteria Community Composition in an Acidic Sphagnum Peat Bog. Applied and Environmental Microbiology, 72, 2110-2117. http://dx.doi.org/10.1128/AEM.72.3.2110-2117.2006

[39] Männistö, M.K., Rawat, S., Starovoytov, V. and Häggblom, M.M. (2012) Granulicella arctica sp. nov., Granulicella mallensis sp. nov., Granulicella tundricola sp. nov. and granulicella sapmiensis sp. nov., Novel Acidobacteria from Tundra Soil. International Journal of Systematic and Evolutionary Microbiology, 62, 2097-2106. http://dx.doi.org/10.1099/ijs.0.031864-0

[40] Pankratov, T.A. and Dedysh, S.N. (2010) Granulicella paludicola gen. nov., sp. nov., Granulicella pectinivorans sp. nov., Granulicella aggregans sp. nov. and granulicella rosea sp. nov., Acidophilic, Polymer-Degrading Acidobacteria from Sphagnum Peat Bogs. International Journal of Systematic and Evolutionary Microbiology, 60, 2951-2959. http://dx.doi.org/10.1099/ijs.0.021824-0

[41] Pankratov, T.A., Ivanova, A.O., Dedysh, S.N. and Liesack, W. (2011) Bacterial Populations and Environmental Factors Controlling Cellulose Degradation in an Acidic Sphagnum Peat. Environmental Microbiology, 13, 1800-1814. http://dx.doi.org/10.1111/j.1462-2920.2011.02491.x

[42] Ward, N.L., Challacombe, J.F., Janssen, P.H., Henrissat, B., Coutinho, P.M., Wu, M., Kuske, C.R., et al. (2009) Three Genomes from the Phylum Acidobacteria Provide Insight into the Lifestyles of These Microorganisms in Soils. Applied and Environmental Microbiology, 75, 2046-2056. http://dx.doi.org/10.1128/AEM.02294-08

[43] Pankratov, T.A., Kirsanova, L.A., Kaparullina, E.N., Kevbrin, V.V. and Dedysh, S.N. (2012) Telmatobacter bradus gen. nov., sp. nov., a Cellulolytic Facultative Anaerobe from Subdivision 1 of the Acidobacteria, and Emended Description of Acidobacterium capsulatum kishimoto et al. 1991. International Journal of Systematic and Evolutionary Microbiology, 62, 430-437. http://dx.doi.org/10.1099/ijs.0.029629-0

[44] Rheims, H., Rainey, F.A. and Stackebrandt, E. (1996) A Molecular Approach to Search for Diversity among Bacteria in the Environment. Journal of Industrial Microbiology, 17, 159-169. http://dx.doi.org/10.1007/BF01574689

[45] García-Moyano, A., Gonzáles-Toril, E., Aguilera, A. and Amils, R. (2007) Prokaryotic Community Composition and Ecology of Floating Macroscopic Filaments from an Extreme Acidic Environment, RÍO Tinto (SW, Spain). Systematic and Applied Microbiology, 30, 601-614. http://dx.doi.org/10.1016/j.syapm.2007.08.002

[46] Kimoto, K.I., Aizawa, T., Urai, M., Ve, N.B., Suzuki, K.I., Nakajima, M. and Sunairi, M. (2010) Acidocella aluminiidurans sp. nov., an Aluminium-Tolerant Bacterium Isolated from Panicum repens Grown in a Highly Acidic Swamp in Actual Acid Sulfate Soil Area of Vietnam. International Journal of Systematic and Evolutionary Microbiology, 60, 764-768. http://dx.doi.org/10.1099/ijs.0.011569-0

[47] Wichlacz, P.L., Unz, R.F. and Langworthy, T.A. (1986) Acidiphilium angustum sp. nov., Acidiphilium facilis sp. nov., and Acidiphilium rubrum sp. nov.: Acidophilic Heterotrophic Bacteria Isolated from Acidic Coal Mine Drainage. International Journal of Systematic and Evolutionary Microbiology, 36, 197-201. http://dx.doi.org/10.1099/00207713-36-2-197

[48] Nazaries, L., Murrell, J.C., Millard, P., Baggs, L. and Singh, B.K. (2013) Methane, Microbes and Models: Fundamental Understanding of the Soil Methane Cycle for Future Predictions. Environmental Microbiology, 15, 2395-2417. http://dx.doi.org/10.1111/1462-2920.12149

[49] Vecherskaya, M., Dijkema, C., Saad, H.R. and Stams, A.J.M. (2009) Microaerobic and Anaerobic Metabolism of a Methylocystis parvus Strain Isolated from a Denitrifying Bioreactor. Environmental Microbiology Reports, 1, 442-449. http://dx.doi.org/10.1111/j.1758-2229.2009.00069.x

[50] Oude Elferink, S.J.W.H., Akkermans-Van Vliet, W.M., Bogte, J.J. and Stams, A.J.M. (1999) Desulfobacca acetoxidans gen. nov., sp. nov., a Novel Acetate-Degrading Sulfate Reducer Isolated from Sulfidogenic Granular Sludge. International Journal of Systematic Bacteriology, 49, 345-350.

[51] Mcinerney, M.J., Struchtemeyer, C.G., Sieber, J., Mouttaki, H., Stams, A.J., Schink, B., Rohlin, L. and Gunsalus, R.P. (2008) Physiology, Ecology, Phylogeny, and Genomics of Microorganisms Capable of Syntrophic Metabolism. Annals of the New York Academy of Sciences, 1125, 58-72. http://dx.doi.org/10.1196/annals.1419.005

[52] Chauhan, A. and Ogram, A. (2006) Phylogeny of Acetate-Utilizing Microorganisms in Soils along a Nutrient Gradient in the Florida Everglades. Applied and Environmental Microbiology, 72, 6837-6840. http://dx.doi.org/10.1128/AEM.01030-06

[53] Puglisi, E., Zaccone, C., Cappa, F., Cocconcelli, P.S., Shotyk, W., Trevisan, M. and Miano, T.M. (2014) Changes in Bacterial and Archaeal Community Assemblages along an Ombrotrophic Peat Bog Profile. Biology and Fertility of Soils, 50, 815-826.

[54] Stoecker, K., Bendinger, B., Schoning, B., Nielsen, P.H., Nielsen, J.L., Baranyi, C., Toenshoff, E.R., Daims, H. and 
Wagner, M. (2006) Cohn's Crenothrix Is a Filamentous Methane Oxidizer with an Unusual Methane Monooxygenase. Proceedings of the National Academy of Sciences of the United States of America, 103, 2363-2367. http://dx.doi.org/10.1073/pnas.0506361103

[55] Kalyuzhnaya, M.G., Yang, S., Rozova, O.N., Smalley, N.E., Clubb, J., Lamb, A., Nagana Gowda, G.A., Raftery, D., Fu, Y., Bringel, F., Vuilleumier, S., Beck, D.A.C., Trotsenko, Y.A., Khmelenina, V.N. and Lidstrom, M.E. (2013) Highly Efficient Methane Biocatalysis Revealed in a Methanotrophic Bacterium. Nature Communications, 4, No. 2785. http://dx.doi.org/10.1038/ncomms3785

[56] Alfreider, A., Vogt, C. and Babel, W. (2002) Microbial Diversity in an in Situ Reactor System Treating Monochlorobenzene Contaminated Groundwater as Revealed by 16S Ribosomal DNA Analysis. Systematic and Applied Microbiology, 25, 232-240. http://dx.doi.org/10.1078/0723-2020-00111

[57] Hug, L.A., Castelle, C.J., Wrighton, K.C., Thomas, B.C., Sharon, I., Frischkorn, K.R., Banfield, J.F., et al. (2013) Community Genomic Analyses Constrain the Distribution of Metabolic Traits across the Chloroflexi Phylum and Indicate Roles in Sediment Carbon Cycling. Microbiome, 1, 22. http://dx.doi.org/10.1186/2049-2618-1-22

[58] Löffler, F.E., Yan, J., Ritalahti, K.M., Adrian, L., Edwards, E.A., Konstantinidis, K.T., Müller, J.A., Fullerton, H., Zinder, S.H. and Spormann, A.M. (2013) Dehalococcoides mccartyi gen. nov., sp. nov., Obligately OrganohalideRespiring Anaerobic Bacteria Relevant to Halogen Cycling and Bioremediation, Belong to a Novel Bacterial Class, Dehalococcoidia Classis nov., Order Dehalococcoidales ord. nov. and Family Dehalococcoidaceae fam. nov., within the Phylum Chloroflexi. International Journal of Systematic and Evolutionary Microbiology, 63, 625-635. http://dx.doi.org/10.1099/ijs.0.034926-0

[59] Biester, H., Martinez Cortizas, A. and Keppler, F. (2006) Occurrence and Fate of Halogens in Mires. In: Martini, I.P., Cortizas, A.M. and Chesworth, W., Eds., Peatlands: Evolution and Records of Environmental and Climate Changes, Elsevier Series Development in Earth Surface Processes, Vol. 9, Elsevier, Amsterdam, 449-465.

[60] Blazejak, A. and Schippers, A. (2010) High Abundance of JS-1- and Chloroflexi-Related Bacteria in Deeply Buried Marine Sediments Revealed by Quantitative, Real-Time PCR. FEMS Microbiology Ecology, 72, 198-207. http://dx.doi.org/10.1111/j.1574-6941.2010.00838.x

[61] Yamada, T., Sekiguchi, Y., Imachi, H., Kamagata, Y., Ohashi, A. and Harada, H. (2005) Diversity, Localization, and Physiological Properties of Filamentous Microbes Belonging to Chloroflexi Subphylum I in Mesophilic and Thermophilic Methanogenic Sludge Granules. Applied and Environmental Microbiology, 71, 7493-7503. http://dx.doi.org/10.1128/AEM.71.11.7493-7503.2005

[62] Wang, Y., Sheng, H.F., He, Y., Wu, J.Y., Jiang, Y.X., Tam, N.F.Y. and Zhou, H.W. (2012) Comparison of the Levels of Bacterial Diversity in Freshwater, Intertidal Wetland, and Marine Sediments by Using Millions of Illumina Tags. Applied and Environmental Microbiology, 78, 8264-8271. http://dx.doi.org/10.1128/AEM.01821-12

[63] Sekiguchi, Y., Yamada, T., Hanada, S., Ohashi, A., Harada, H. and Kamagata, Y. (2003) Anaerolinea thermophila gen. nov., sp. nov. and Caldilinea aerophila gen. nov., sp. nov., Novel Filamentous Thermophiles that Represent a Previously Uncultured Lineage of the Domain Bacteria at the Subphylum Level. International Journal of Systematic and Evolutionary Microbiology, 53, 1843-1851. http://dx.doi.org/10.1099/ijs.0.02699-0

[64] Lienen, T., Kleyböcker, A., Brehmer, M., Kraume, M., Moeller, L., Görsch, K. and Würdemann, H. (2013) Floating Layer Formation, Foaming, and Microbial Community Structure Change in Full-Scale Biogas Plant Due to Disruption of Mixing and Substrate Overloading. Energy, Sustainability and Society, 3, 20.

http://dx.doi.org/10.1186/2192-0567-3-20

[65] Huang, X.F., Liu, Y.J., Dong, J.D., Qu, L.Y., Zhang, Y.Y., Wang, F.Z., Tian, X.P. and Zhang, S. (2014) Mangrovibacterium diazotrophicum gen. nov., sp. nov., a Nitrogen-Fixing Bacterium Isolated from a Mangrove Sediment, and Proposal of Prolixibacteraceae fam. nov. International Journal of Systematic and Evolutionary Microbiology, 64, 875-881. http://dx.doi.org/10.1099/ijs.0.052779-0

[66] Van Passel, M.W., Kant, R., Palva, A., Copeland, A., Lucas, S., Lapidus, A., Smidt, H., et al. (2011) Genome Sequence of the Verrucomicrobium Opitutus terrae PB90-1, an Abundant Inhabitant of Rice Paddy Soil Ecosystems. Journal of Bacteriology, 193, 2367-2368. http://dx.doi.org/10.1128/JB.00228-11

[67] Isanapong, J., Goodwin, L., Bruce, D., Chen, A., Detter, C., Han, J., Rodrigues, J.L., et al. (2012) High-Quality Draft Genome Sequence of the Opitutaceae Bacterium Strain TAV1, a Symbiont of the Wood-Feeding Termite Reticulitermes flavipes. Journal of Bacteriology, 194, 2744-2745. http://dx.doi.org/10.1128/JB.00264-12

[68] Sangwan, P., Kovac, S., Davis, K.E., Sait, M. and Janssen, P.H. (2005) Detection and Cultivation of Soil Verrucomicrobia. Applied and Environmental Microbiology, 71, 8402-8410. http://dx.doi.org/10.1128/AEM.71.12.8402-8410.2005

[69] Khadem, A.F., Pol, A., Wieczorek, A., Mohammadi, S.S., Francoijs, K.J., Stunnenberg, H.G., Jetten, M. and Op den Camp, H.J.M. (2011) Autotrophic Methanotrophy in Verrucomicrobia: Methylacidiphilum fumariolicum solv Uses the Calvin-Benson-Bassham Cycle for Carbon Dioxide Fixation. Journal of Bacteriology, 193, 4438-4446. 
http://dx.doi.org/10.1128/JB.00407-11

[70] Fukunaga, Y., Kurahashi, M., Sakiyama, Y., Ohuchi, M., Yokota, A. and Harayama, S. (2009) Phycisphaera mikurensis gen. nov., sp. nov., Isolated from a Marine Alga, and Proposal of Phycisphaeraceae fam. nov., Phycisphaerales ord. nov. and Phycisphaerae Classis nov. in the Phylum Planctomycetes. Journal of General and Applied Mirobiology, 55, 267-275. http://dx.doi.org/10.2323/igam.55.267

[71] Kulichevskaya, I.S., Baulina, O.I., Bodelier, P.L.E., Rijpstra, W.I.C., Damsté, J.S.S. and Dedysh, S.N. (2009) Zavarzinella formosa gen. nov., sp. nov., a Novel Stalked, Gemmata-Like Planctomycete from a Siberian Peat Bog. International Journal of Systematic and Evolutionary Microbiology, 59, 357-364. http://dx.doi.org/10.1099/ijs.0.002378-0

[72] Kulichevskaya, I.S., Serkebaeva, Y.M., Kim, Y., Rijpstra, W.I.C., Damsté, J.S.S., Liesack, W. and Dedysh, S.N. (2012) Telmatocola sphagniphila gen. nov., sp. nov., a Novel Dendriform Planctomycete from Northern Wetlands. Frontiers in Microbiology, 3, 146. http://dx.doi.org/10.3389/fmicb.2012.00146

[73] Yoon, J., Jang, J.H. and Kasai, H. (2014) Algisphaera agarilytica gen. nov., sp. nov., a Novel Representative of the Class Phycisphaerae within the Phylum Planctomycetes Isolated from a Marine Alga. Antonie van Leeuwenhoek, 105, 317-324. http://dx.doi.org/10.1007/s10482-013-0076-1

[74] Ivanova, A.O. and Dedysh, S.N. (2012) Abundance, Diversity and Depth Distribution of Planctomycetes in Acidic Northern Wetlands. Frontiers in Microbiology, 3, 5. http://dx.doi.org/10.3389/fmicb.2012.00005

[75] Strous, M., Fuerst, J.A., Kramer, E.H., Logemann, S., Muyzer, G., Van De Pas-Schoonen, K.T., Webb, R., Kuenen, J.G. and Jetten, M.S. (1999) Missing Lithotroph Identified as New Planctomycete. Nature, 400, 446-449. http://dx.doi.org/10.1038/22749

[76] Bragina, A., Maier, S., Berg, C., Müller, H., Chobot, V., Hadacek, F. and Berg, G. (2011) Similar Diversity of Alphaproteobacteria and Nitrogenase Gene Amplicons on Two Related Sphagnum Mosses. Frontiers in Microbiology, 2, 275.

[77] Hugenholtz, P., Pitulle, C., Hershberger, K.L. and Pace, N.R. (1998) Novel Division Level Bacterial Diversity in a Yellowstone Hot Spring. Journal of Bacteriology, 180, 366-376.

[78] Farag, I.F., Davis, J.P., Youssef, N.H. and Elshahed, M.S. (2014) Global Patterns of Abundance, Diversity and Community Structure of the Aminicenantes (Candidate Phylum OP8). PLoS ONE, 9, e92139. http://dx.doi.org/10.1371/journal.pone.0092139

[79] Wu, M.L., Van Teeseling, M.C., Willems, M.J., Van Donselaar, E.G., Klingl, A., Rachel, R. and Van Niftrik, L. (2012) Ultrastructure of the Denitrifying Methanotroph "Candidatus Methylomirabilis Oxyfera," a Novel Polygon-Shaped Bacterium. Journal of Bacteriology, 194, 284-291. http://dx.doi.org/10.1128/JB.05816-11

[80] Ettwig, K.F., Butler, M.K., Le Paslier, D., Pelletier, E., Mangenot, S., Kuypers, M.M.M., Schreiber, F., Dutilh, B.E., Zedelius, J., De Beer, D., Gloerich, J., Wessels, H.J.C.T., Van Alen, T., Luesken, F., Wu, M.L., Van De Pas-Schoonen, K.T., Op Den Camp, H.J.M., Janssen-Megens, E.M., Francoijs, K.J., Stunnenberg, H., Weissenbach, J., Jetten, M.S.M. and Strous, M. (2010) Nitrite-Driven Anaerobic Methane Oxidation by Oxygenic Bacteria. Nature, 464, 543-548. http://dx.doi.org/10.1038/nature08883 


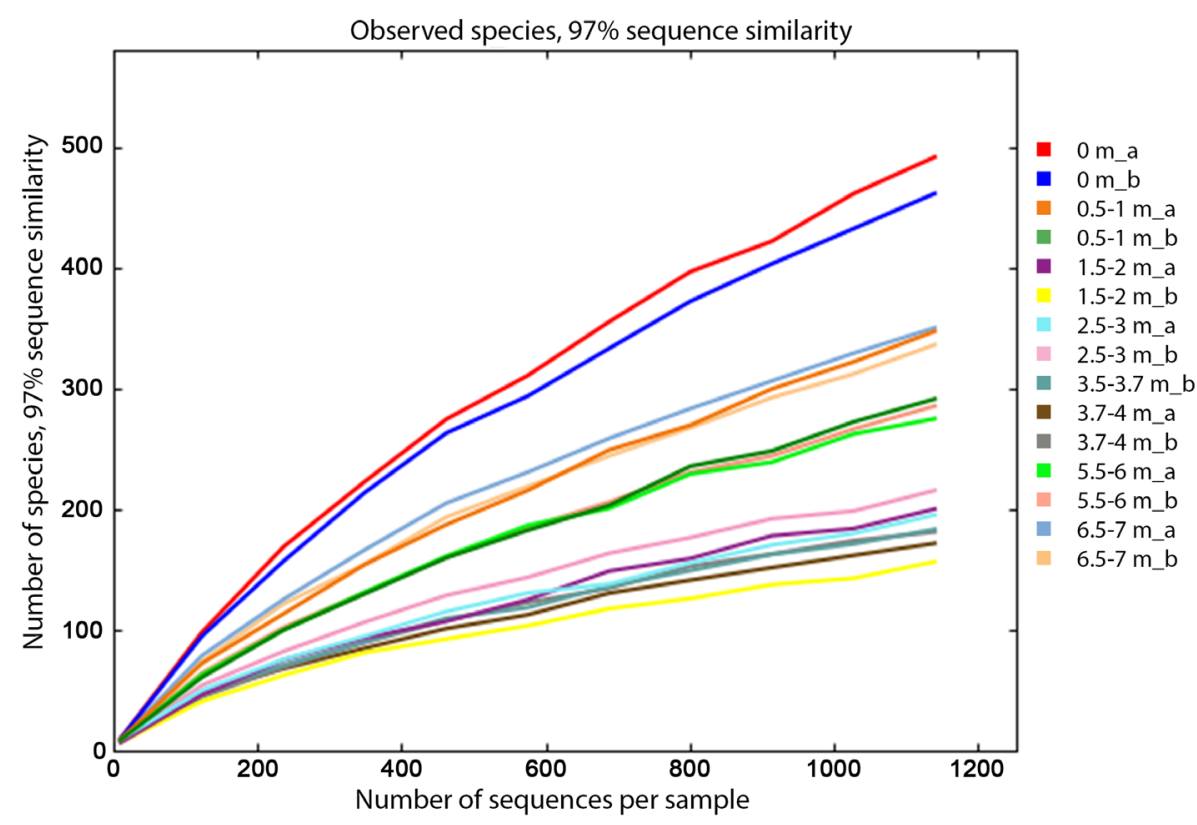

Figure S1. Rarefaction analysis showing the number of different bacterial 16S rRNA gene sequences detected per number of randomly picked sequences. The sequence reads were grouped into Operational Taxonomic Units (OTUs) sharing $>97 \%$ sequence similarity between sequence reads. Samples are named as in Table 2.

Table S1. Heat map showing the abundance as percentage (\%) of total number of sequence reads designated to different taxonomic groups atthe different depths of the bog profile. The colouring describes low (green), medium (yellow) and high (red) relative abundance of sequence reads).

\begin{tabular}{|c|c|c|c|c|c|c|c|c|c|c|c|c|}
\hline \multirow{2}{*}{ Phylum } & \multirow{2}{*}{ Class } & \multirow{2}{*}{ Order } & \multirow{2}{*}{ Family } & \multirow[b]{2}{*}{ Genus } & \multicolumn{8}{|c|}{ Relative amount at different depths* } \\
\hline & & & & & $\mathbf{0 ~ m}$ & $\begin{array}{c}0.5-1 \\
\mathrm{~m}\end{array}$ & $\begin{array}{c}1.5-2.0 \\
\mathrm{~m}\end{array}$ & $\begin{array}{c}2.5-3.0 \\
\mathrm{~m}\end{array}$ & $\begin{array}{c}\text { 3.5-3.7 } \\
\text { m }\end{array}$ & $\begin{array}{c}3.7-4.0 \\
\mathrm{~m}\end{array}$ & $\begin{array}{c}5.5-6.0 \\
m\end{array}$ & $\begin{array}{c}\text { 6.5-7.0 } \\
\mathrm{m}\end{array}$ \\
\hline \multicolumn{5}{|c|}{ Unclassified } & 0.04 & 0.75 & 0.06 & 0.02 & 0.34 & & 0.05 & 0.15 \\
\hline \multicolumn{5}{|c|}{ Bacteria } & 1.48 & 1.47 & 0.85 & 0.70 & 1.30 & 1.86 & 3.62 & 18.77 \\
\hline \multirow{2}{*}{$\mathrm{AC} 1$} & \multicolumn{4}{|c|}{ HDBW-WB69 } & & & & & & & & 0.08 \\
\hline & \multicolumn{4}{|c|}{ SHA-114 } & & & & & & & 0.07 & 0.20 \\
\hline AD3 & \multicolumn{4}{|c|}{ JG37-AG-4 } & & 0.09 & 0.10 & 0.03 & 0.05 & 0.08 & 0.04 & \\
\hline \multirow{11}{*}{ 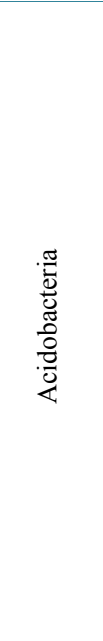 } & \multirow{8}{*}{\multicolumn{3}{|c|}{$\begin{array}{l}\cdot \frac{\pi}{0} \\
\frac{0}{0} \\
\frac{\pi}{0} \\
0 \\
\frac{0}{0} \\
\frac{0}{4}\end{array}$}} & & 0.56 & 2.70 & 1.94 & 1.36 & 0.76 & 0.22 & 0.47 & 0.30 \\
\hline & & & & Other & 0.73 & 1.66 & 0.63 & 0.55 & 0.14 & 0.22 & 0.27 & \\
\hline & & & & nclassified & & & 0.00 & & & & & \\
\hline & & & & Other & 2.20 & 2.70 & 2.67 & 11.74 & 7.79 & 0.44 & 0.98 & 0.08 \\
\hline & & & & Unclassified & 14.92 & 8.23 & 5.24 & 6.19 & 2.78 & 6.52 & 2.86 & 0.19 \\
\hline & & & & Acidobacterium & & & 0.01 & 0.01 & & & & \\
\hline & & & & Edaphobacter & 0.01 & 0.02 & 0.00 & 0.04 & & & 0.00 & \\
\hline & & & & Granulicella & 2.16 & 1.18 & 1.17 & 2.35 & 1.75 & 0.03 & 0.33 & \\
\hline & & & \multirow{3}{*}{ 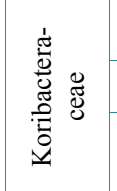 } & Other & 0.61 & 0.96 & 0.45 & 0.15 & 0.02 & 0.21 & 0.16 & 0.03 \\
\hline & & & & Unclassified & 8.47 & 7.70 & 6.74 & 1.40 & 0.54 & 2.57 & 1.73 & 0.38 \\
\hline & & & & $\begin{array}{l}\text { Candidatus } \\
\text { Koribacter }\end{array}$ & 0.48 & 0.61 & 0.38 & 0.53 & 0.93 & 1.15 & 0.17 & 0.03 \\
\hline
\end{tabular}


I. Tsitko et al.

\section{Continued}

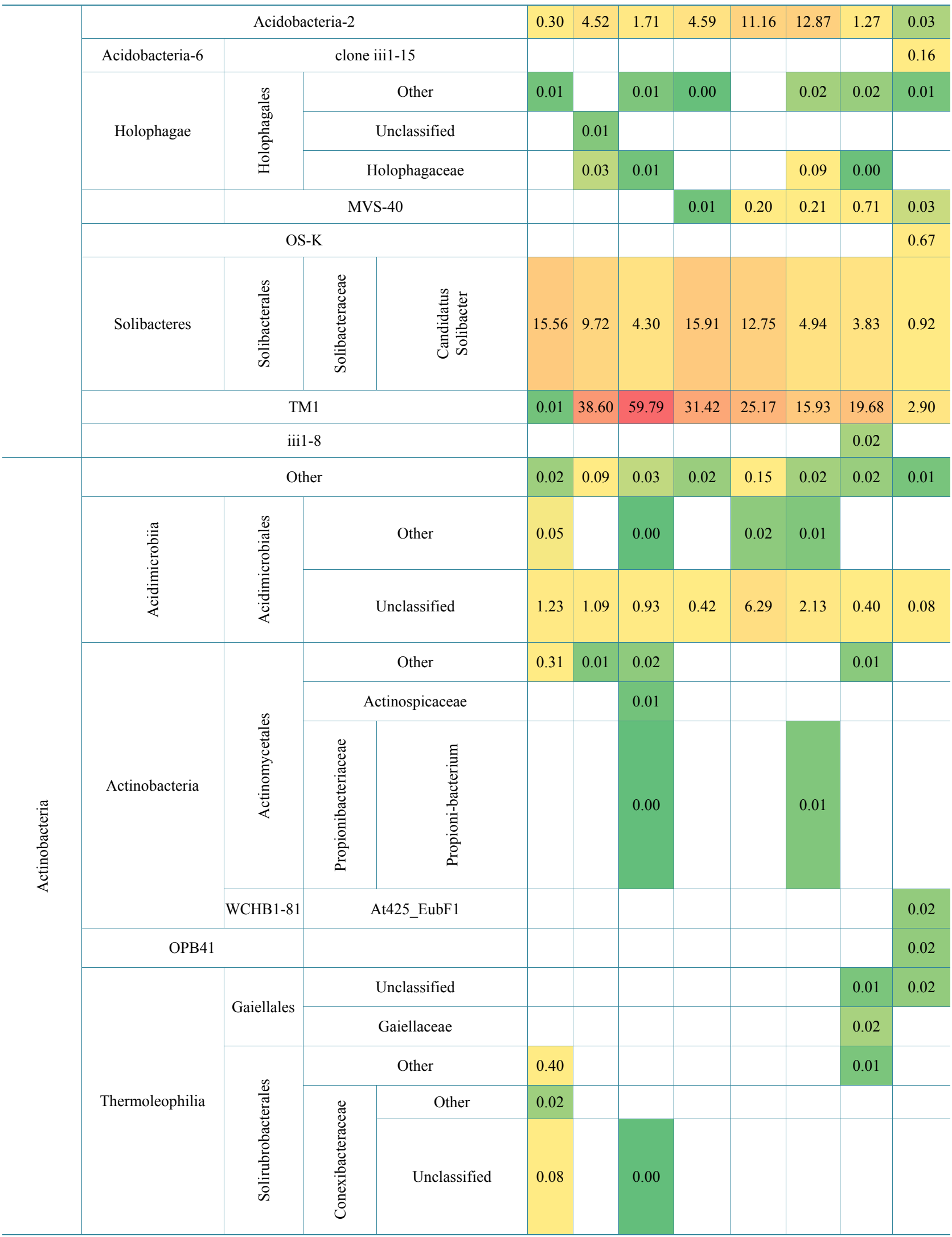




\section{Continued}

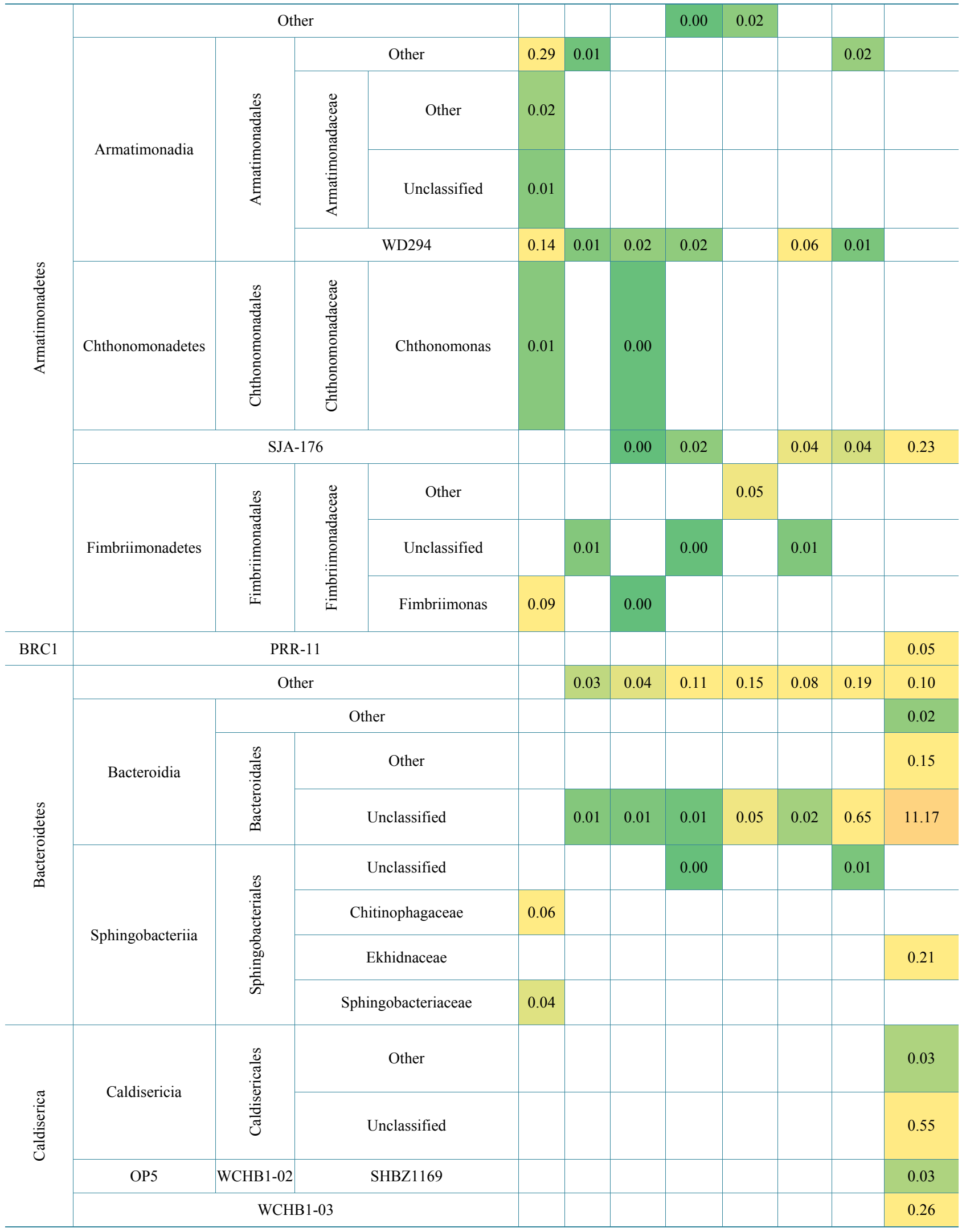


I. Tsitko et al.

\section{Continued}

\begin{tabular}{|c|c|c|c|c|c|c|c|c|c|c|c|}
\hline \multirow{8}{*}{$\begin{array}{l}\overrightarrow{0} \\
\frac{0}{0} \\
\text { 류 }\end{array}$} & \multirow{5}{*}{ BSV26 } & \multicolumn{3}{|c|}{ A89 } & & & & & & 0.06 & \\
\hline & & \multicolumn{3}{|c|}{ BSN164 } & 0.01 & 0.00 & & & & & \\
\hline & & \multicolumn{3}{|c|}{$\mathrm{C} 20$} & & & & & & 0.15 & 0.28 \\
\hline & & \multicolumn{3}{|c|}{ PK329 } & & & & & & 0.15 & \\
\hline & & \multicolumn{3}{|c|}{ VC38 } & & & 0.01 & & 0.03 & 0.00 & \\
\hline & & \multicolumn{3}{|c|}{ Other } & & & 0.00 & 0.02 & & & \\
\hline & Ignavibacteria & $\frac{\tilde{\theta}}{\cdot \frac{\pi}{0}}$ & \multicolumn{2}{|c|}{ Ignavibacteriaceae } & 0.01 & 0.01 & 0.05 & 0.06 & & & \\
\hline & & \multicolumn{3}{|c|}{ SJA-28 } & & & & 0.03 & & 0.04 & 0.36 \\
\hline \multirow{23}{*}{ 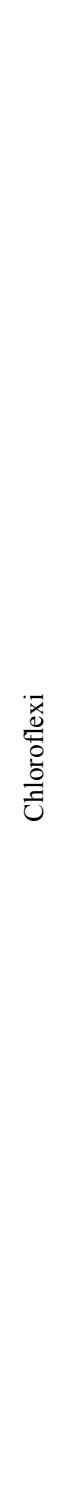 } & & \multicolumn{3}{|c|}{ Other } & & & & 0.02 & 0.04 & 0.90 & 0.21 \\
\hline & \multirow{12}{*}{ 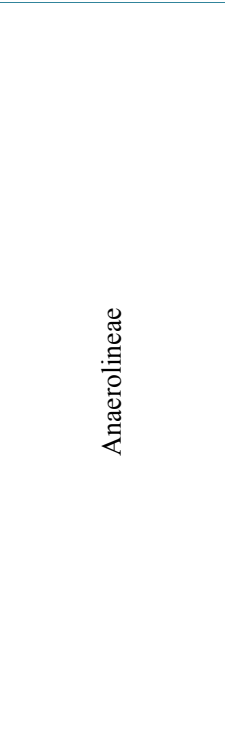 } & \multicolumn{3}{|c|}{ Other } & & & & & & 0.15 & 1.85 \\
\hline & & \multicolumn{3}{|c|}{ A31 } & & & & & & 0.01 & 0.08 \\
\hline & & \multirow{4}{*}{ 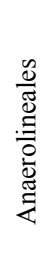 } & \multicolumn{2}{|c|}{ Other } & & & & & & & 0.02 \\
\hline & & & $\underset{\pi}{\mathscr{2}}$ & Other & & & & & & 0.02 & 0.11 \\
\hline & & & $\stackrel{\Xi}{0}$ & Unclassified & & & & & & 0.03 & 0.67 \\
\hline & & & & C1_B004 & & & & & & & 0.03 \\
\hline & & \multicolumn{3}{|c|}{ GCA004 } & & & & & & & 0.11 \\
\hline & & \multicolumn{3}{|c|}{ H39 } & & & & & & 0.01 & 0.06 \\
\hline & & \multicolumn{3}{|c|}{ SB-34 } & & & & & & & 0.06 \\
\hline & & \multicolumn{3}{|c|}{ SJA-15 } & & & 0.00 & 0.02 & 0.01 & & \\
\hline & & \multicolumn{3}{|c|}{ envOPS12 } & & & & 0.03 & & 2.38 & 0.13 \\
\hline & & \multicolumn{3}{|c|}{ pLW-97 } & & & & & & & 0.96 \\
\hline & \multirow{6}{*}{ Dehalococcoidetes } & \multicolumn{3}{|c|}{ Other } & & 0.01 & 0.04 & 0.14 & 0.07 & 1.31 & 1.83 \\
\hline & & \multicolumn{3}{|c|}{ Unclassified } & 0.19 & 0.31 & 2.26 & 1.30 & 0.08 & 4.20 & 2.19 \\
\hline & & \multirow{2}{*}{ 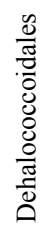 } & \multirow{2}{*}{ 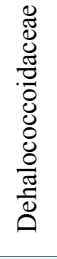 } & Other & & & & & & 0.00 & 0.05 \\
\hline & & & & Unclassified & & & & & & 0.09 & 0.52 \\
\hline & & & FS1 & -02 & & & & & & 0.03 & 0.14 \\
\hline & & & & & 1.84 & 2.78 & 2.53 & 6.33 & 34.69 & 4.17 & 6.96 \\
\hline & & & & & & & 0.13 & 0.08 & 0.04 & 0.23 & 0.39 \\
\hline & & & & & & & & & & & 0.05 \\
\hline & & & & & & & & & & & 0.02 \\
\hline & TK17 & & & & & & & & & & 0.39 \\
\hline
\end{tabular}


I. Tsitko et al.

\section{Continued}

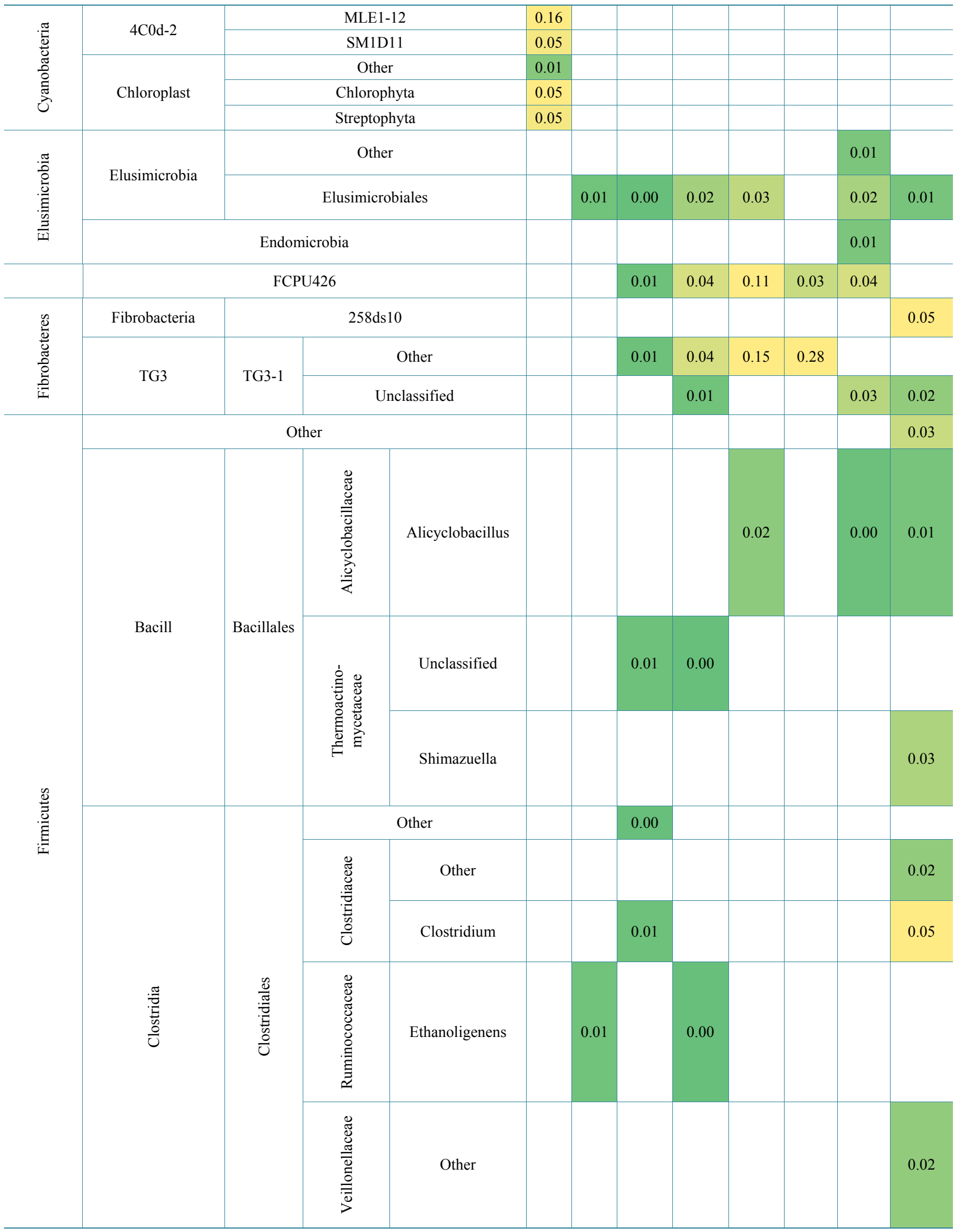




\section{Continued}

\begin{tabular}{|c|c|c|c|c|c|c|c|c|c|c|c|c|}
\hline & & SHA-98 & & D2 & & & & & & & & 1.57 \\
\hline GN04 & \multicolumn{4}{|c|}{ MSB-5A5 } & & & & & & & & 0.03 \\
\hline \multicolumn{5}{|c|}{ GOUTA4 } & & & & & & & & 0.02 \\
\hline 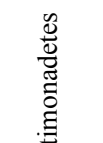 & \multicolumn{4}{|c|}{ Gemm-1 } & & & & & & & 0.08 & \\
\hline \multicolumn{5}{|c|}{ Lentisphaerae } & & 0.04 & 0.02 & 0.01 & & 0.04 & & \\
\hline \multirow{3}{*}{$\mathrm{NC} 10$} & \multicolumn{4}{|c|}{ Unclassified } & & & & & & & & 0.08 \\
\hline & \multirow{2}{*}{$12-24$} & & \multicolumn{2}{|c|}{ Other } & & & & & & & 0.01 & \\
\hline & & & \multicolumn{2}{|c|}{ JH-WHS47 } & & & 0.03 & & & 0.13 & 0.25 & 1.86 \\
\hline \multirow{2}{*}{ NKB19 } & \multicolumn{4}{|c|}{ Other } & & & & & & & & 0.06 \\
\hline & \multicolumn{4}{|c|}{ Unclassified } & & & & & & & & 0.05 \\
\hline 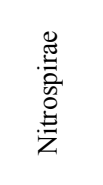 & Nitrospira & 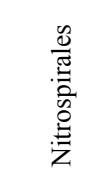 & 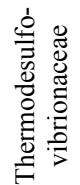 & & & & 0.01 & & & & 0.02 & \\
\hline \multirow{5}{*}{ OD1 } & \multicolumn{4}{|c|}{ Other } & & & 0.00 & 0.05 & 0.08 & 0.01 & 0.03 & \\
\hline & \multicolumn{4}{|c|}{ Unclassified } & & & & & & & 0.01 & \\
\hline & \multicolumn{4}{|c|}{$\mathrm{ABY} 1$} & & & & & & & 0.01 & \\
\hline & \multicolumn{4}{|c|}{ SM2F11 } & & & & & & & 0.01 & \\
\hline & \multicolumn{4}{|c|}{ ZB2 } & & & & & & 0.03 & 0.02 & \\
\hline $\mathrm{OP} 1$ & \multicolumn{4}{|c|}{ MSBL6 } & & & & & & & & 0.02 \\
\hline OP11 & \multicolumn{4}{|c|}{ Other } & & & & & & & 0.01 & \\
\hline \multirow{3}{*}{ OP3 } & \multicolumn{4}{|c|}{ BD4-9 } & & & & 0.00 & & & 0.05 & \\
\hline & \multirow{2}{*}{ koll11 } & \multirow{2}{*}{ GIF 10} & & classified & & & & & & 0.06 & 0.02 & 0.02 \\
\hline & & & & kpj58rc & 0.01 & 0.02 & 0.01 & 0.03 & & 0.01 & & \\
\hline \multirow{4}{*}{ OP8 } & \multirow{3}{*}{ OP8_1 } & \multicolumn{3}{|c|}{ Other } & & & & & & & 7.89 & 0.32 \\
\hline & & \multicolumn{3}{|c|}{ Unclassified } & & & & & & & & 3.95 \\
\hline & & \multicolumn{3}{|c|}{ SHA-124 } & & & & & & & 0.13 & 1.21 \\
\hline & \multicolumn{4}{|c|}{ OP8_2 } & & & & & & & & 0.07 \\
\hline
\end{tabular}




\section{Continued}

\begin{tabular}{|c|c|c|c|c|c|c|c|c|c|c|c|c|}
\hline \multirow{13}{*}{ 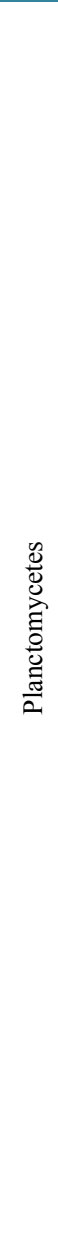 } & \multicolumn{4}{|c|}{ Other } & & 0.01 & 0.01 & 0.01 & & 0.02 & 0.00 & 0.12 \\
\hline & \multicolumn{4}{|c|}{ Unclassified } & & & & & & & & 4.56 \\
\hline & ODP123 & \multicolumn{3}{|c|}{ T8-B82 } & & 0.03 & 0.03 & 0.07 & 0.02 & 0.12 & 0.08 & \\
\hline & \multirow{2}{*}{ Phycisphaerae } & \multicolumn{3}{|c|}{ Unclassified } & 0.80 & 0.19 & 0.08 & 6.32 & 8.98 & 1.74 & 3.00 & 1.90 \\
\hline & & \multicolumn{3}{|c|}{ Phycisphaerales } & 0.01 & & & 0.01 & 0.02 & 0.02 & & \\
\hline & \multirow{7}{*}{ 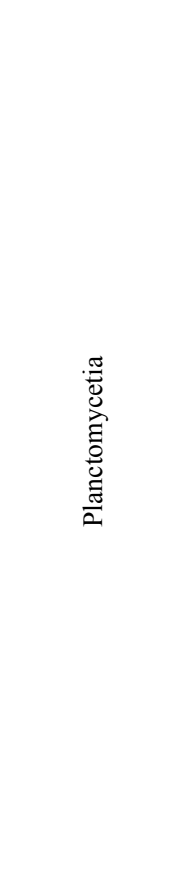 } & \multirow{4}{*}{ 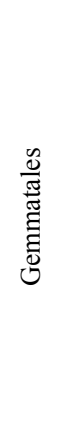 } & \multirow{2}{*}{ 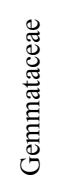 } & Unclassified & 0.18 & 0.01 & & & & & & \\
\hline & & & & Gemmata & 0.88 & 0.01 & & & & & & \\
\hline & & & \multirow{2}{*}{$\begin{array}{l}\mathscr{\Xi} \\
\mathbb{\Xi} \\
\mathbb{\Xi} \\
\mathbb{\Xi} \\
\tilde{\Xi} \\
\tilde{0} \\
0 \\
0\end{array}$} & Other & 0.13 & & & & & & & \\
\hline & & & & Unclassified & 0.23 & 0.01 & 0.01 & & & & 0.01 & \\
\hline & & \multirow[b]{2}{*}{ 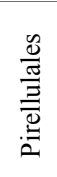 } & \multirow{2}{*}{ 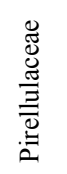 } & Other & & & 0.00 & & & & & \\
\hline & & & & Unclassified & 0.01 & 0.23 & 0.10 & 0.18 & 0.43 & 0.83 & 1.26 & 0.30 \\
\hline & & 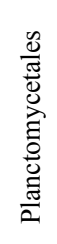 & 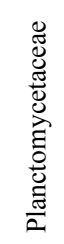 & Planctomyces & 0.05 & & & & & & & \\
\hline & vadinHA49 & \multicolumn{3}{|c|}{ p04_C01 } & & 0.01 & 0.01 & 0.01 & & 0.07 & & 0.08 \\
\hline \multirow{12}{*}{ 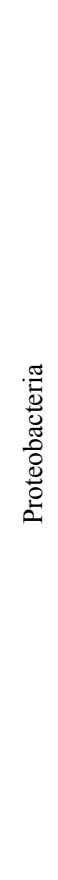 } & \multicolumn{4}{|c|}{ Other } & 0.32 & 0.09 & 0.01 & 0.03 & 0.02 & & 0.00 & 0.20 \\
\hline & \multirow{11}{*}{ 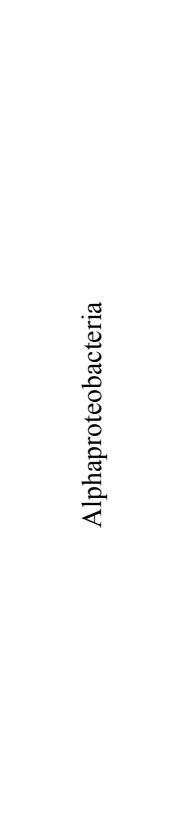 } & \multicolumn{3}{|c|}{ Other } & 1.54 & 0.08 & 0.05 & 0.01 & 0.05 & 0.08 & 0.01 & \\
\hline & & \multicolumn{3}{|c|}{ Unclassified } & 0.32 & & & & & & & \\
\hline & & \multirow{5}{*}{ 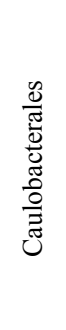 } & \multicolumn{2}{|c|}{ Unclassified } & & 0.02 & & & & & & \\
\hline & & & \multirow{4}{*}{ 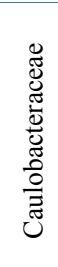 } & Other & 1.40 & & 0.01 & & & 0.01 & & \\
\hline & & & & Unclassified & 0.89 & & 0.01 & & & & & \\
\hline & & & & Asticcacaulis & 0.04 & & & & & & & \\
\hline & & & & Caulobacter & 0.03 & & & & & & & \\
\hline & & \multicolumn{3}{|c|}{ Ellin329 } & 0.94 & 0.02 & 0.02 & 0.02 & 0.05 & 0.08 & 0.09 & 0.02 \\
\hline & & \multirow{3}{*}{ 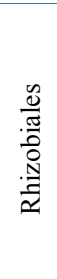 } & \multirow[b]{3}{*}{ 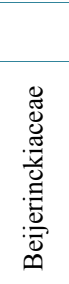 } & ther & 0.79 & 1.90 & 0.48 & 0.22 & 0.09 & 1.26 & 0.09 & 0.03 \\
\hline & & & & Other & 0.03 & 0.02 & 0.03 & & & & & \\
\hline & & & & Methylocella & 0.01 & 0.09 & 0.04 & & & & & \\
\hline
\end{tabular}




\section{Continued}

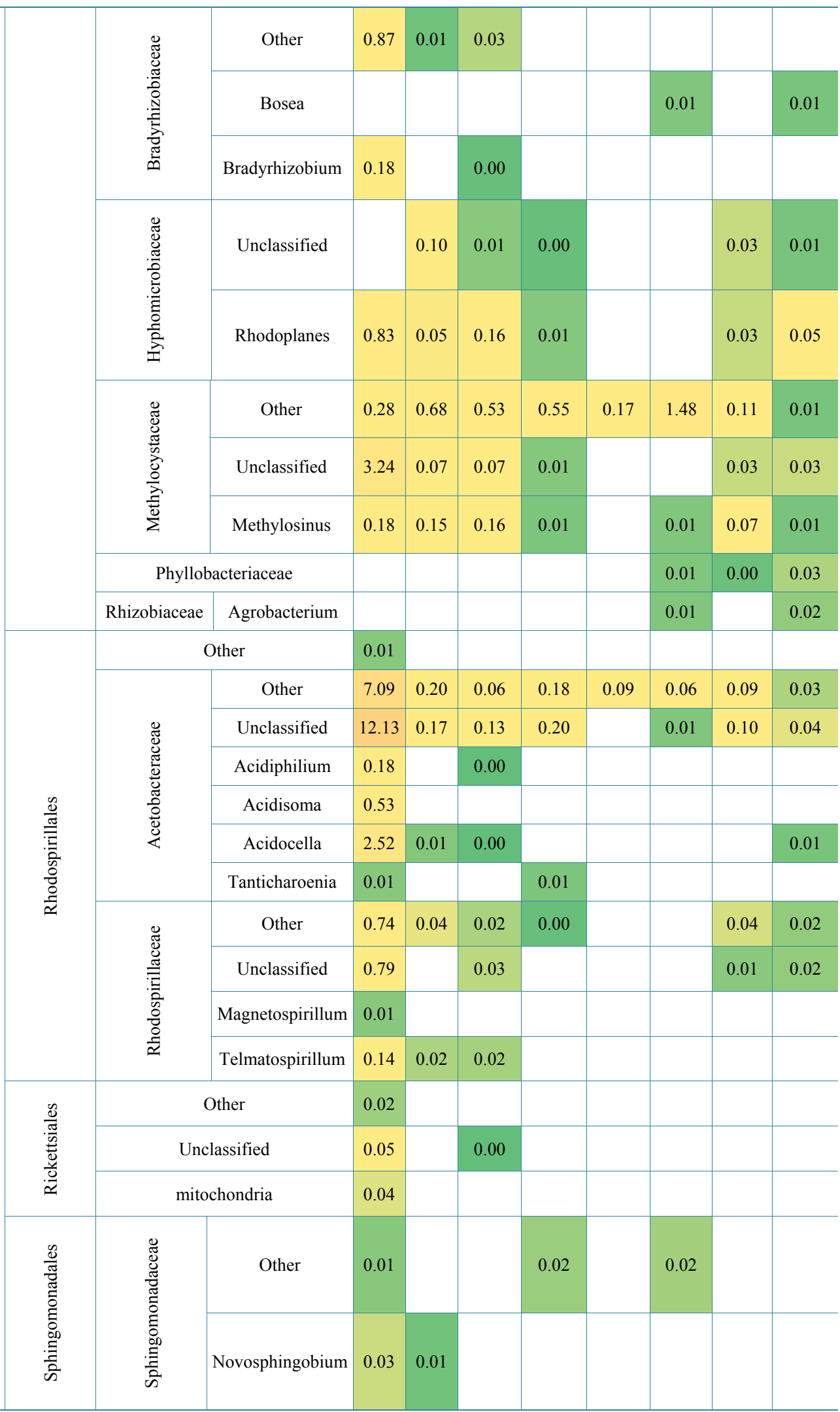




\section{Continued}

\begin{tabular}{|c|c|c|c|c|c|c|c|c|c|c|c|}
\hline \multirow{10}{*}{ 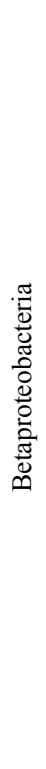 } & \multicolumn{3}{|c|}{ Other } & 1.54 & & & & & & & 0.14 \\
\hline & \multirow{6}{*}{ 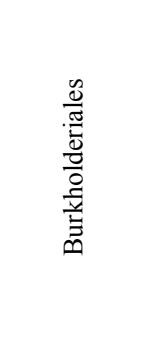 } & \multirow{5}{*}{ 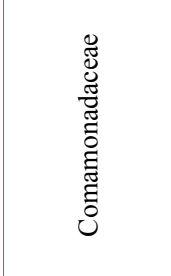 } & Other & & & & & & & & 0.45 \\
\hline & & & Curvibacter & & & & & & & & 0.03 \\
\hline & & & Delftia & & & & & & & & 0.05 \\
\hline & & & Hydrogenophaga & & & & & & & & 1.78 \\
\hline & & & Variovorax & & & & & & & & 0.02 \\
\hline & & \multicolumn{2}{|c|}{ Oxalobacteraceae } & 0.09 & & & & & & & \\
\hline & Neisseriales & Neisseriaceae & Chromobacterium & 0.01 & & & & & & & \\
\hline & 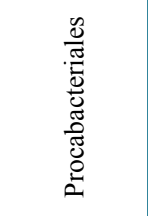 & & 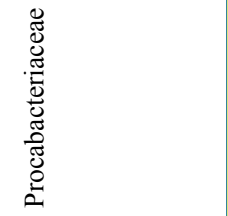 & 0.04 & & & & & & & \\
\hline & \multicolumn{3}{|c|}{ SBla14 } & & 0.02 & & & & & & \\
\hline \multirow{13}{*}{ 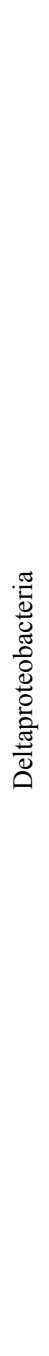 } & \multicolumn{3}{|c|}{ Other } & & 0.05 & 0.01 & 0.01 & & & 0.01 & 0.32 \\
\hline & \multicolumn{3}{|c|}{ ВРC076 } & & & & & & & 3.31 & 2.60 \\
\hline & 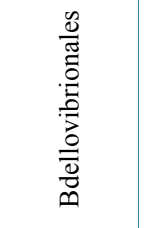 & 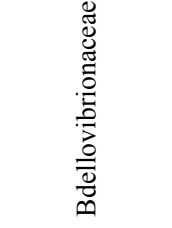 & $\begin{array}{l}\frac{0}{0} \\
\frac{0}{3} \\
\frac{0}{0} \\
\frac{0}{0}\end{array}$ & 0.01 & & & & & & & \\
\hline & 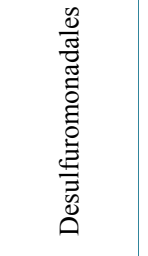 & 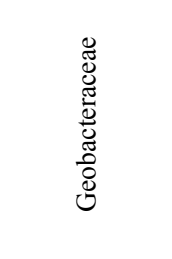 & 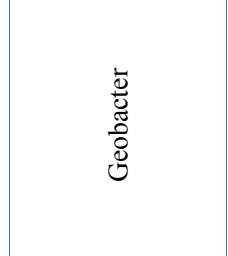 & & 0.07 & 0.02 & & & & 0.00 & \\
\hline & \multicolumn{3}{|c|}{ FAC87 } & 0.01 & & & & & & & \\
\hline & \multicolumn{3}{|c|}{ MIZ46 } & 0.03 & & & & & & & \\
\hline & \multirow{4}{*}{ 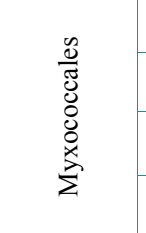 } & \multicolumn{2}{|r|}{ Other } & 0.01 & & & & & & & \\
\hline & & \multicolumn{2}{|c|}{ Unclassified } & 0.09 & 0.01 & & 0.01 & 0.05 & & 0.21 & 0.04 \\
\hline & & \multicolumn{2}{|c|}{ Haliangiaceae } & 0.01 & & & & & & & \\
\hline & & \multicolumn{2}{|c|}{ Мухососcасеаe } & 0.01 & & & & & & & \\
\hline & \multirow{3}{*}{ 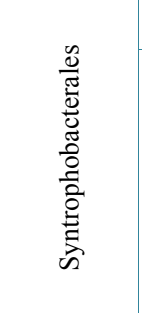 } & \multicolumn{2}{|r|}{ Other } & & 0.01 & 0.01 & 0.01 & 0.02 & 0.04 & 0.06 & 0.15 \\
\hline & & \multirow{2}{*}{ 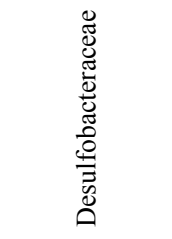 } & Other & & & & & & & & 0.20 \\
\hline & & & Desulfobacterium & & & & & & & & 0.06 \\
\hline
\end{tabular}


I. Tsitko et al.

\section{Continued}

\begin{tabular}{|c|c|c|c|c|c|c|c|c|c|c|c|c|}
\hline & & & \multirow{4}{*}{ 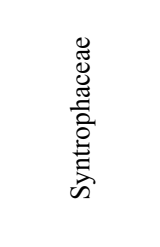 } & Other & & 0.22 & 0.00 & 0.02 & 0.03 & 0.27 & 0.13 & 0.31 \\
\hline & & & & Unclassified & & & & 0.01 & & 0.01 & 0.03 & 1.04 \\
\hline & & & & Desulfobacca & & 2.99 & 2.10 & 0.34 & 0.02 & 0.04 & 0.52 & 0.03 \\
\hline & & & & Syntrophus & & 0.29 & 0.02 & 0.04 & 0.06 & 0.18 & 0.09 & 1.26 \\
\hline & & & \multirow{3}{*}{ 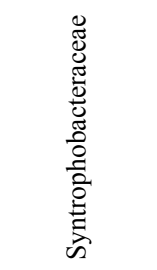 } & Unclassified & & 0.01 & & & & & 0.01 & \\
\hline & & & & Syntrophobacter & & 0.09 & 0.18 & 0.28 & 0.03 & 0.08 & 0.11 & 0.03 \\
\hline & & & & Unclassified & & 0.38 & 0.25 & 0.43 & 0.23 & 0.77 & 0.82 & 0.87 \\
\hline & \multirow{9}{*}{ 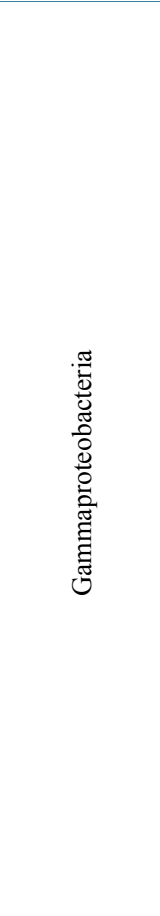 } & \multicolumn{3}{|c|}{ Other } & 0.08 & & & & & & & 0.03 \\
\hline & & \multirow{4}{*}{ 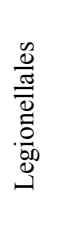 } & \multicolumn{2}{|c|}{ Other } & 0.03 & & & & & & & \\
\hline & & & \multicolumn{2}{|c|}{ Unclassified } & 0.05 & & 0.00 & & & & 0.01 & \\
\hline & & & \multirow{2}{*}{ Coxiellaceae } & Unclassified & 0.04 & & & & & & & \\
\hline & & & & Aquicella & 0.01 & & & & & & & \\
\hline & & \multirow[b]{2}{*}{ 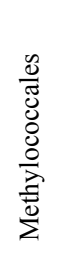 } & \multicolumn{2}{|c|}{ Other } & & & & & & & & 0.02 \\
\hline & & & 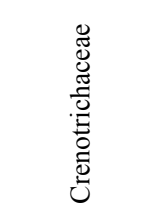 & Crenothrix & & & & & & & & 1.78 \\
\hline & & \multirow[b]{2}{*}{ 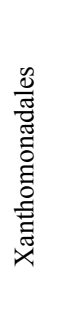 } & \multicolumn{2}{|c|}{ Sinobacteraceae } & 4.07 & 0.01 & 0.03 & & & & & \\
\hline & & & 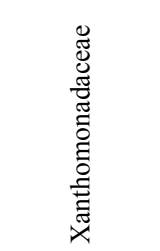 & 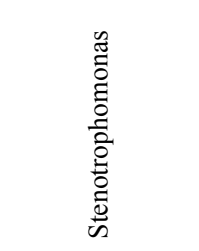 & & & & 0.00 & & & & 0.01 \\
\hline \multicolumn{5}{|c|}{$\mathrm{SC} 4$} & & & & & & & 0.02 & 0.11 \\
\hline \multirow{4}{*}{ 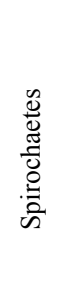 } & \multirow{4}{*}{ Spirochaetes } & \multicolumn{3}{|c|}{ M2PT2-76 } & & & & 0.01 & & & & \\
\hline & & y & $\ddot{\mathscr{J}}$ & Other & & 0.01 & 0.00 & & 0.02 & 0.02 & 0.03 & 0.16 \\
\hline & & $\frac{\mathbb{J}}{\tilde{J}}$ & 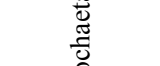 & Spirochaeta & & 0.06 & 0.07 & 0.06 & 0.28 & 0.51 & 12.39 & 15.74 \\
\hline & & $\omega$ & के & Treponema & & & 0.01 & 0.01 & & 0.02 & & \\
\hline \multirow{2}{*}{ TM6 } & \multicolumn{4}{|c|}{ Other } & & & & 0.01 & & & & \\
\hline & \multicolumn{4}{|c|}{ SBRH58 } & & 0.03 & & & & & & \\
\hline TM7 & \multicolumn{4}{|c|}{ TM7-1 } & 0.03 & 0.13 & 0.04 & 0.03 & & 0.01 & 0.04 & 0.01 \\
\hline
\end{tabular}




\section{Continued}

\begin{tabular}{|c|c|c|c|c|c|c|c|c|c|c|c|c|}
\hline \multirow{15}{*}{ 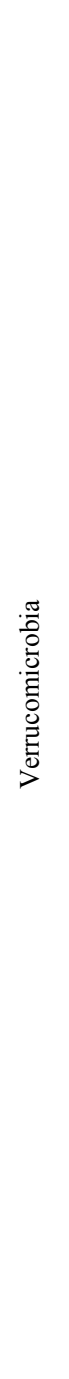 } & \multicolumn{4}{|c|}{ Other } & & 0.03 & 0.01 & 0.01 & 0.02 & 0.01 & 0.01 & \\
\hline & \multirow{4}{*}{ Opitutae } & \multirow{4}{*}{ Opitutales } & \multicolumn{2}{|c|}{ Other } & & & & & & & 0.01 & \\
\hline & & & \multirow{3}{*}{ Opitutaceae } & Other & & 0.01 & & 0.03 & 1.45 & 0.08 & 10.61 & 0.08 \\
\hline & & & & Unclassified & & & & & & & 0.01 & \\
\hline & & & & Opitutus & 0.43 & 0.04 & 0.08 & 0.43 & 0.40 & 0.11 & 0.55 & 0.03 \\
\hline & \multirow{3}{*}{ Methylacidiphilae } & \multirow{2}{*}{ 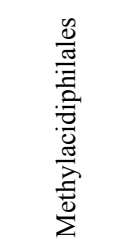 } & \multicolumn{2}{|c|}{ Other } & 0.01 & & & & & & & \\
\hline & & & \multicolumn{2}{|c|}{ Unclassified } & 0.46 & 0.01 & 0.01 & 0.01 & & & & \\
\hline & & \multicolumn{3}{|c|}{ S-BQ2-57 } & & 0.04 & 0.10 & 0.01 & 0.08 & 0.26 & 0.96 & \\
\hline & \multirow{5}{*}{ Pedosphaerae } & \multirow{5}{*}{ 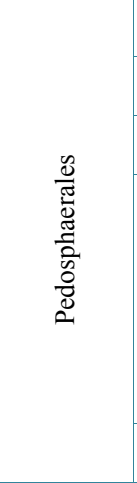 } & \multicolumn{2}{|c|}{ Other } & 0.10 & 2.57 & 1.43 & 0.95 & 0.88 & 2.13 & 1.94 & 0.03 \\
\hline & & & \multicolumn{2}{|c|}{ Unclassified } & 0.01 & 0.34 & 0.20 & 0.32 & 0.23 & 0.06 & 0.28 & 0.01 \\
\hline & & & \multicolumn{2}{|c|}{ Ellin515 } & & 3.71 & 2.80 & 3.28 & 1.98 & 4.10 & 1.96 & 0.02 \\
\hline & & & 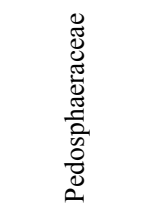 & Pedosphaera & 0.02 & & 0.00 & & & & & \\
\hline & & & \multicolumn{2}{|c|}{ auto67_4W } & 0.05 & 0.24 & 0.12 & 2.99 & 3.54 & 0.11 & 0.49 & 0.04 \\
\hline & \multirow{2}{*}{ Spartobacteria } & \multirow{2}{*}{ 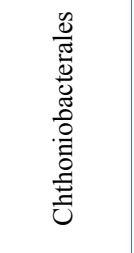 } & \multirow{2}{*}{ 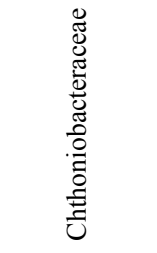 } & Other & 0.13 & & & & & & & \\
\hline & & & & Unclassified & 0.14 & & 0.01 & & & & & \\
\hline \multicolumn{3}{|c|}{ WPS-2 } & & & 3.30 & 0.04 & 0.08 & & 0.02 & & 0.04 & \\
\hline \multicolumn{3}{|c|}{ WS1 } & & & & & & 0.02 & & & 0.01 & 0.08 \\
\hline \multirow{2}{*}{$\frac{\tilde{N}}{3}$} & \multicolumn{2}{|c|}{ Kazan-3B-09 } & & & & & & & & & & 0.04 \\
\hline & \multicolumn{2}{|c|}{ SHA-109 } & & & & & & & & & & 0.03 \\
\hline WS3 & PRR-12 & \multicolumn{3}{|c|}{ PBS-III-9 } & & & & & & & & 0.08 \\
\hline \multicolumn{5}{|c|}{ WS4 } & & & 0.00 & 0.01 & & & & \\
\hline
\end{tabular}

Table S2. Spearman Rank correlationbetween peat characteristics andrichness (Chao 1 values), diversity (Shannon index H') and abundance of 16S RNA gene.

\begin{tabular}{cccc}
\hline Peat parameters & Richness & Diversity & Abundance of 16S rRNA gene $\left(\operatorname{copy} \log 10 \mathrm{~g}^{-1} \mathrm{DW}\right)$ \\
\hline Depth & -0.25 & -0.17 & $-0.57^{*}$ \\
pH value & -0.06 & 0.08 & $-0.50^{*}$ \\
Moisture content & -0.01 & -0.21 & $0.86^{* *}$ \\
Organic matter content & $-0.76^{* *}$ & $-0.74^{* *}$ & 0.33 \\
\hline
\end{tabular}

\footnotetext{
"Significance at $p=0.05$ level; ${ }^{* *}$ Significance at $p=0.01$ level.
} 
Table S3. Spearman Rank correlation between the relative abundances of the major bacterial phyla and classes and the peat characteristics.

\begin{tabular}{|c|c|c|c|c|}
\hline Phylum/Class & depth & $\mathrm{pH}$ & Moisture & organics \\
\hline \multicolumn{5}{|l|}{ Acidobacteria } \\
\hline Acidobacteria-1 & $-0.98^{* *}$ & $-0.86^{*}$ & 0.26 & 0.27 \\
\hline Acidobacteria-2 & 0.05 & -0.07 & 0.31 & $0.93^{* *}$ \\
\hline Holophagae & 0.12 & 0.12 & -0.10 & -0.17 \\
\hline Solibacteres & -0.67 & -0.52 & 0.24 & 0.61 \\
\hline TM1 & -0.29 & -0.48 & -0.17 & 0.41 \\
\hline \multicolumn{5}{|l|}{ Proteobacteria } \\
\hline Alphaproteobacteria & $-0.81^{*}$ & -0.69 & 0.33 & 0.15 \\
\hline Betaproteobacteria & -0.11 & 0.08 & -0.11 & -0.70 \\
\hline Deltaproteobacteria & 0.60 & 0.52 & -0.62 & -0.61 \\
\hline Gammaproteobacteria & -0.20 & -0.20 & -0.17 & $-0.81^{*}$ \\
\hline \multicolumn{5}{|l|}{ Chloroflexi } \\
\hline Anaerolineae & $0.95^{* *}$ & $0.95^{* *}$ & -0.27 & -0.28 \\
\hline Dehalococcoidetes & $0.93^{* *}$ & $0.86^{* *}$ & -0.19 & 0.05 \\
\hline Other Chloroflexi & $0.85^{* *}$ & $0.85^{* *}$ & -0.54 & -0.25 \\
\hline \multicolumn{5}{|l|}{ Verrucomicrobia } \\
\hline Opitutaceae & 0.456 & 0.201 & -0.024 & 0.087 \\
\hline Methylacidiphilae & 0.185 & 0.035 & 0.199 & 0.213 \\
\hline Pedosphaerales & -0.151 & -0.411 & 0.241 & 0.533 \\
\hline Ellin515 & -0.224 & -0.554 & 0.082 & 0.590 \\
\hline auto67_4W & 0.047 & -0.250 & -0.217 & 0.274 \\
\hline Actinobacteria & -0.36 & -0.29 & $0.93^{* *}$ & 0.54 \\
\hline Unclassified Bacteria & 0.60 & $0.71^{*}$ & -0.07 & $-0.71^{*}$ \\
\hline Spirochaetes & $0.98^{* *}$ & $0.86^{* *}$ & -0.26 & -0.27 \\
\hline Candidate division $\mathrm{NC10}$ & $0.81^{*}$ & 0.68 & -0.36 & -0.53 \\
\hline Bacteroidetes & $0.74^{* *}$ & $0.76^{* *}$ & -0.29 & -0.39 \\
\hline Firmicutes & 0.35 & 0.19 & -0.25 & -0.07 \\
\hline Aminicenantes (Group OP8) & $0.73^{*}$ & $0.73^{*}$ & -0.48 & $-0.75^{*}$ \\
\hline Planctomycetes & 0.64 & $0.71^{*}$ & -0.12 & 0.07 \\
\hline Candidate Division WPS-2 & $-0.73^{*}$ & $-0.73^{*}$ & 0.44 & -0.28 \\
\hline
\end{tabular}

"Significance at $\mathrm{p}=0.05$ level; ${ }^{* *}$ Significance at $\mathrm{p}=0.01$ level. 
Scientific Research Publishing (SCIRP) is one of the largest Open Access journal publishers. It is currently publishing more than 200 open access, online, peer-reviewed journals covering a wide range of academic disciplines. SCIRP serves the worldwide academic communities and contributes to the progress and application of science with its publication.

Other selected journals from SCIRP are listed as below. Submit your manuscript to us via either submit@scirp.org or Online Submission Portal.
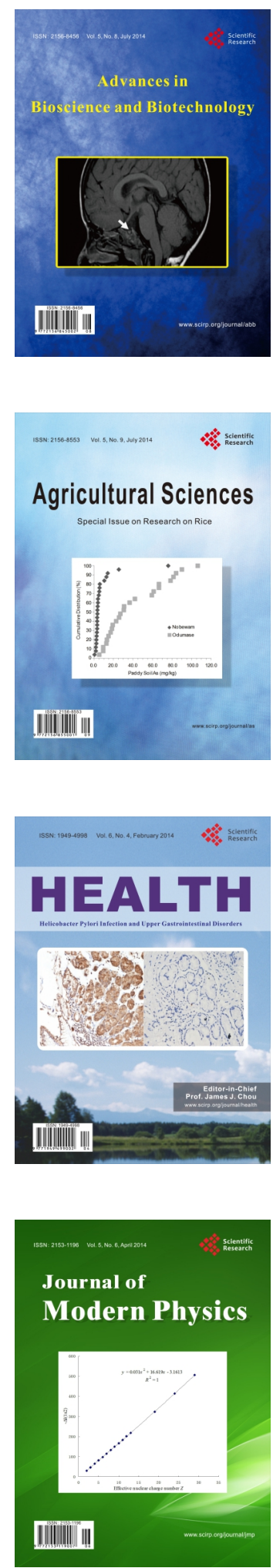
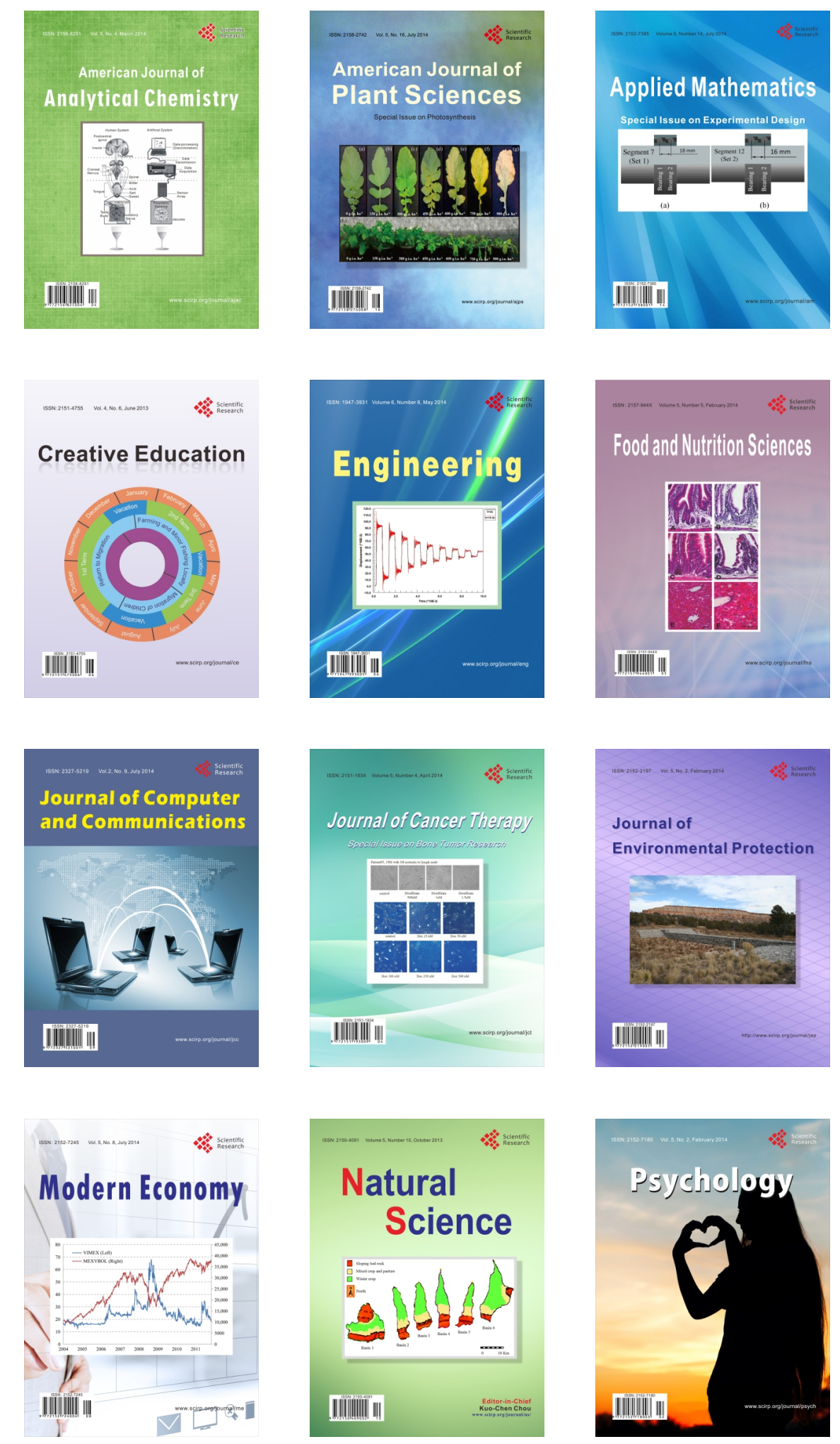